\title{
SIMULATIONS OF FLOW IN THE EDWARDS-TRINITY AQUIFER SYSTEM AND CONTIGUOUS HYDRAULICALLY CONNECTED UNITS, WEST-CENTRAL TEXAS
}

\author{
U.S. GEOLOGICAL SURVEY
}

Water-Resources Investigations Report 93-4039
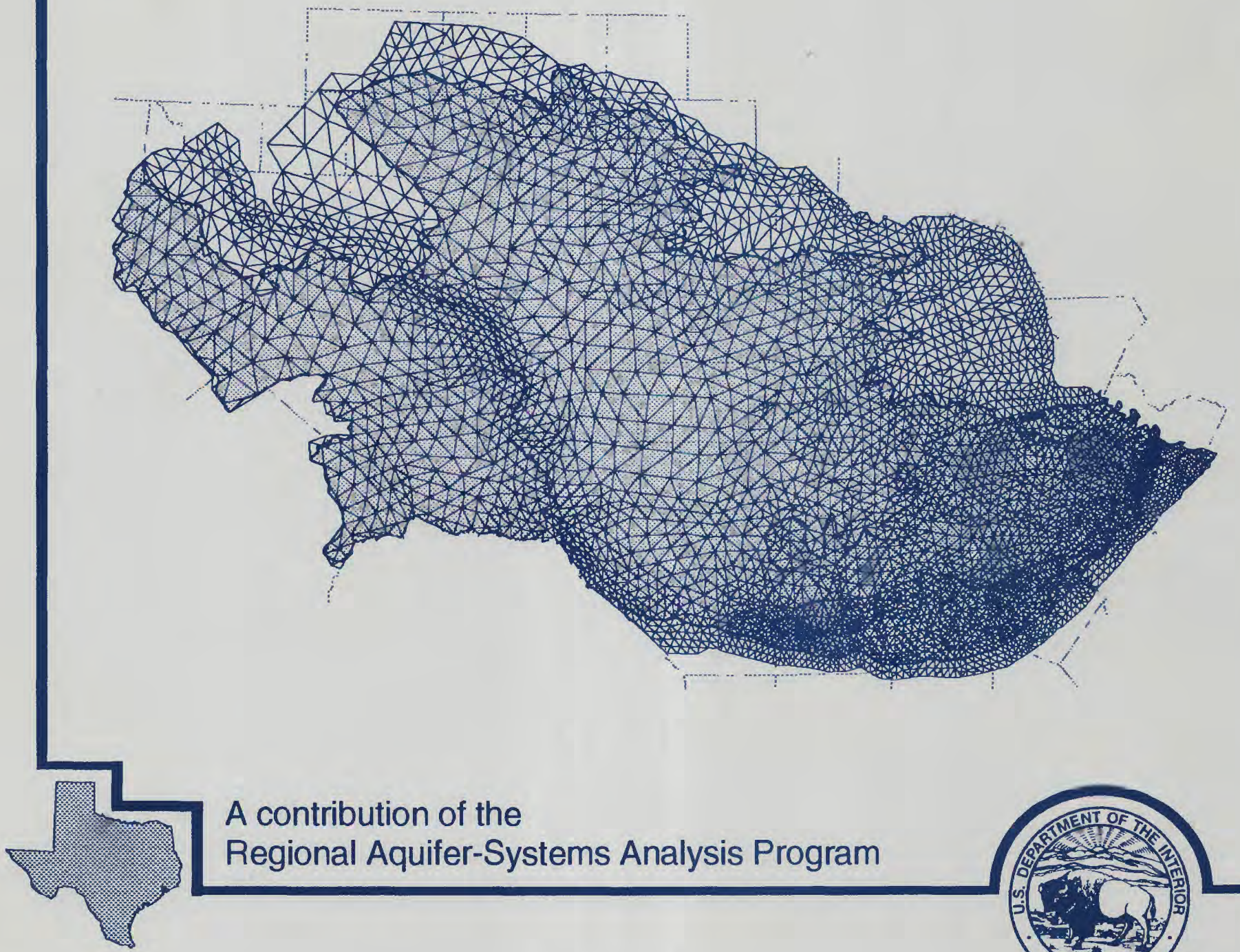

A contribution of the

Regional Aquifer-Systems Analysis Program

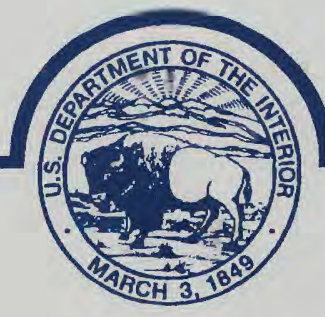





\section{SIMULATIONS OF FLOW IN THE EDWARDS-TRINITY AQUIFER SYSTEM AND CONTIGUOUS HYDRAULICALLY CONNECTED UNITS, WEST-CENTRAL TEXAS}

By Eve L. Kuniansky and Kelly Q. Holligan

\section{U.S. GEOLOGICAL SURVEY}

Water-Resources Investigations Report 93-4039

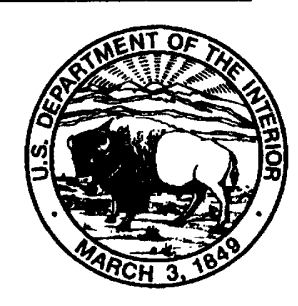

A contribution of the

Regional Aquifer-Systems Analysis Program 


\section{U.S. DEPARTMENT OF THE INTERIOR \\ BRUCE BABBITT, Secretary}

U.S. GEOLOGICAL SURVEY

Gordon P. Eaton, Director

For additional information write to:

Copies of this report can be purchased from:

U.S. Geological Survey

Earth Science Information Center

District Chief

Open-File Reports Section

U.S. Geological Survey 8011 Cameron Rd.

Box 25286, Mail Stop 517

Denver Federal Center

Austin, TX 78754-3898

Denver, CO 80225-0046 


\section{CONTENTS}

Abstract
Introduction
Purpose and Scope
Acknowledgments
Hydrogeologic Setting
Hydrogeologic Units of the Edwards-Trinity Aquifer System and Contiguous Hydraulically
Connected Units

\section{PLATES}

(Plates are in pocket)

1-3. Maps showing:

1. Finite-element mesh and lateral and internal boundaries for the simulation of flow in the EdwardsTrinity aquifer system and contiguous hydraulically connected units, west-central Texas

2. Simulated potentiometric surface of the Edwards-Trinity aquifer system and contiguous hydraulically connected units, west-central Texas, winter 1974-75

3. Magnitude and direction of water movement in the Edwards-Trinity aquifer system and contiguous hydraulically connected units, west-central Texas, winter 1974-75

\section{ILLUSTRATIONS}

1. Map showing location of the study area, geographic subareas, and major aquifers .......................................... 3

2. Map showing location of faults associated with the Balcones fault zone ............................................................. 4

3. Chart showing relation of stratigraphic and hydrogeologic units ........................................................................ 6

4-6. Maps showing:

4. Potentiometric surface of the Edwards-Trinity aquifer system and contiguous hydraulically connected units, west-central Texas, winter 1974-75

5. Historical potentiometric surface of the Edwards-Trinity aquifer system and contiguous hydraulically connected units, west-central Texas, 1915-69

6. Location of municipal, industrial, and irrigation withdrawals, winter 1974-75 .................................... 15

7. Hydrographs from selected wells throughout the study area ................................................................. 16 
8. Generalized section showing the geologic units simulated as one model layer

9-12. Maps showing:

9. Simulated predevelopment potentiometric surface of the Edwards-Trinity aquifer system and contiguous hydraulically connected units, west-central Texas

10. Ranges of transmissivity in the simulations 27

11. Ranges of anisotropy in the simulations 28

12. Ranges of recharge in the preliminary simulations 29

13. Graphs showing sensitivity of the model to variations in parameters and stresses .....

14. Diagram of the water budget components for the major aquifers of the Edwards-Trinity aquifer system and contiguous units, winter 1974-75

15. Diagram of the water budget components for the major aquifers of the Edwards-Trinity aquifer system and contiguous units, predevelopment

\section{TABLES}

1. Records of selected wells with hydrographs

2. Simulated and observed or estimated discharge from major springs

\section{CONVERSION FACTORS, VERTICAL DATUM, AND ABBREVIATED WATER-QUALITY UNIT}

\begin{tabular}{|c|c|c|}
\hline Multiply & By & To obtain \\
\hline acre-foot (acre-ft) & 0.001233 & cubic hectometer \\
\hline acre-foot per foot (acre- $f t / f t)$ & 0.00405 & cubic hectometer per meter \\
\hline acre-foot per year (acre-ft/yr) & 0.001233 & cubic hectometer per year \\
\hline cubic foot per second $\left(\mathrm{ft}^{3} / \mathrm{s}\right)$ & 0.02832 & cubic meter per second \\
\hline cubic foot per second per mile $\left[\left(\mathrm{ft}^{3} / \mathrm{s}\right) / \mathrm{mi}\right]$ & 0.0176 & cubic meter per second per kilometer \\
\hline foot $(\mathrm{ft})$ & 0.3048 & meter \\
\hline foot per day $(f t / d)$ & 0.3048 & meter per day \\
\hline foot squared per day $\left(\mathrm{ft}^{2} / \mathrm{d}\right)$ & 0.09294 & meter squared per day \\
\hline gallon per minute (gal/min) & 0.06309 & liter per second \\
\hline inch (in.) & 25.4 & millimeter \\
\hline inch per year (in/yr) & 25.4 & millimeter per year \\
\hline mile (mi) & 1.609 & kilometer \\
\hline million gallons per day $(\mathrm{Mgal} / \mathrm{d})$ & 3,785 & kiloliter per day \\
\hline \multirow[t]{2}{*}{ square mile $\left(\mathrm{mi}^{2}\right)$} & 2.590 & square kilometer \\
\hline & Temperature & \\
\hline degree Fahrenheit $\left({ }^{\circ} \mathrm{F}\right)$ & ${ }^{\circ} \mathrm{C}=5 / 9 \mathrm{X}\left({ }^{\circ} \mathrm{F}-32\right)$ & degree Celsius $\left({ }^{\circ} \mathrm{C}\right)$ \\
\hline
\end{tabular}

Sea Level: In this report, "sea level" refers to the National Geodetic Vertical Datum of 1929--a geodetic datum derived from a general adjustment of the first-order level nets of the United States and Canada, formerly called Sea Level Datum of 1929.

\section{Abbreviated water-quality unit:}

$\mathrm{mg} / \mathrm{L}$, milligram per liter 


\title{
Simulations of Flow in the Edwards-Trinity Aquifer System and Contiguous Hydraulically Connected Units, West-Central Texas
}

\author{
By Eve L. Kuniansky and Kelly Q. Holligan
}

\section{Abstract}

The Edwards-Trinity aquifer system is currently (1993) being studied as part of the Regional Aquifer-Systems Analysis program. A major goal of the project is to understand and describe the regional ground-water flow system. A finiteelement model for simulating two-dimensional steady-state ground-water flow was applied to the major aquifers of the Edwards-Trinity aquifer system and contiguous hydraulically connected units for the winter of 1974-75 and for the predevelopment conditions. The major aquifers are the Edwards-Trinity in the western semiarid part of the study area, the Trinity in the eastern subhumid part of the study area, and the Edwards in the southeastern part of the study area. The EdwardsTrinity, upper part of the Trinity, and part of the Edwards aquifers are shallow and unconfined over most of the study area. Regional ground-water flow is toward the perennial streams for the Edwards-Trinity and Trinity aquifers, as indicated by the observed and simulated potentiometric surfaces.

The transmissivity values used in the simulations were within estimated ranges and generally are: 1,000 to $10,000 \mathrm{ft}^{2} / \mathrm{d}$ (feet squared per day) for the Edwards-Trinity and Trinity aquifers; 100,000 to greater than 1 million $\mathrm{ft}^{2} / \mathrm{d}$ for the Edwards aquifer; and less than 500 to $10,000 \mathrm{ft}^{2} / \mathrm{d}$ in contiguous hydraulically connected units. Simulated flow through the Edwards-Trinity aquifer system and contiguous hydraulically connected units is about 3 million acre-feet per year. Estimates of areally distributed recharge from the simulations range from 0.1 to 1 inch per year for the Edwards-Trinity aquifer and increase to 4 inches per year for the Trinity aquifer. Recharge to the Edwards aquifer occurs along streambeds that cross outcropped high-permeability rocks of the Edwards Group through joints and faults. Many of the streams are diverted completely underground during periods of no precipitation. The movement of a substantial quantity of water (about 400 cubic feet per second) from the Trinity and EdwardsTrinity aquifers into the Edwards aquifer was simulated. Results of the simulations indicate that anisotropy strongly influences flow in the Edwards aquifer. In the San Antonio and Austin areas, the Edwards aquifer is the most active part of the ground-water flow system with one-third of ground-water discharge occurring in 5 percent of the modeled area for both simulations.

\section{INTRODUCTION}

The Edwards-Trinity aquifer system and contiguous hydraulically connected units underlie $55,600 \mathrm{mi}^{2}$ in west-central Texas. This aquifer system is currently (1993) being studied as part of the U.S. Geological Survey's Regional Aquifer-Systems Analysis (RASA) program. A major goal of the program is to understand and describe the regional flow system. The RASA program was initiated in 1978 in response to the 1977 drought (Sun, 1986, p. 1). Digital ground-water modeling of the aquifer system is a method to quantify water movement through the regional ground-water system and refine estimates of aquifer properties. Thus, the development of a digital ground-water flow model of the aquifer system is a key part of the project.

The steady-state simulations were accomplished using a two-dimensional finite-element model for ground-water flow (Kuniansky, 1990a). The finiteelement method was selected because faulting in different directions throughout the study area, particularly in the southeastem part, results in anisotropy that strongly 
influences regional ground-water flow. The finiteelement method is one of the few numerical methods that can approximate this properly.

\section{Purpose and Scope}

This report is one in a series of reports of the Edwards-Trinity RASA project. It describes the steadystate simulations of ground-water flow in the major aquifers of the Edwards-Trinity aquifer system and contiguous units that form a continuous hydraulically connected flow system within the study area (fig. 1). The model area extends beyond the aquifers of the Edwards-Trinity system to hydrologic divides, including the Colorado River and the Rio Grande. Background hydrologic information, geologic structures that affect ground-water flow within the aquifer system, boundary conditions, sources, and sinks are documented in this report.

The winter of 1974-75 (December 1974 through February 1975) was selected for simulation for three reasons: (1) The system is closest to steady state during winter; (2) during winter there is almost no loss of ground water caused by evaporation, irrigation withdrawals, and transpiration; and (3) more water-level data were available throughout the study area during this winter season than during other winter seasons.

A simulation of predevelopment conditions was accomplished and compared to a historical potentiometric surface. The historical surface was developed from the earliest recorded water levels within the study area (1915-69) and is the best available representation of a predevelopment surface (Bush and others, 1993).

Lack of data prohibit transient calibration of the entire 55,600 $\mathrm{mi}^{2}$ model area. The only period for which an accurate potentiometric surface could be developed over the entire area was winter 1974-75. Few synoptic periods with water levels of the aquifers exist and areal distributions of recharge and discharge adequate for sequential stress periods are not available. Thus, the model developed is the simplest approximation of the regional flow system. This simple approximation is useful for comparison of water budgets and flow directions of the predevelopment and postdevelopment simulations.

\section{Physiography and Hydrologic Setting}

The area of the Edwards-Trinity aquifer system in west-central Texas is divided into four geographic subareas: Trans-Pecos, Edwards Plateau, Hill Country, and Balcones fault zone (fig.1). The Trans-Pecos is characterized by the flat alluvial valley of the Pecos River on the north and east, and by highly dissected flat plateaus and mesas in the south. Altitudes in the TransPecos range from $1,200 \mathrm{ft}$ in the south to 4,500 ft at the eastern edge of the Davis Mountains (Rees and Buckner, 1980, p. 2). A series of mountain ranges bounds this subarea on the west. The Edwards Plateau, located in the center of the study area, is characterized by "***rolling plains to flat tableland and rugged, steep-walled canyons and draws***" ranging in altitude from 1,000 to 3,300 ft (Walker, 1979, p. 7). The Hill Country subarea is characterized by rough rolling terrain ranging in altitude from 800 to $2,400 \mathrm{ft}$ (Ashworth, 1983, p. 2). The Balcones fault zone in the southern part of the study area is characterized by an escarpment created by a series of en echelon faults, which trend southwest to northeast along the length of the subarea (fig. 2). In the eastern part of the Balcones fault zone, the altitude of land surface ranges from about 500 to $1,000 \mathrm{ft}$. In the western part of the Balcones fault zone, altitudes range from about 500 to $1,500 \mathrm{ft}$.

The major rivers that drain west-central Texas are the Colorado, Guadalupe, Nueces, and Pecos Rivers, and the Rio Grande (pl. 1). Many of these rivers are incised into the Edwards-Trinity aquifer system. Base flow, consisting of ground-water discharge to streams, ranged from 25 to 90 percent of the total streamflow for December 1974 through March 1977 in the eastern part of the study area (Kuniansky, 1989).

The climate varies from subhumid subtropical in the east to arid temperate in the northwest. There are two rainy seasons in the eastern part of the study area, one in spring and one in fall. Storms in the eastern part of the area usually are widespread. In the western part of the study area, precipitation usually occurs in the summer. These summer storms may be intense, but are local in extent. Precipitation has the greatest spatial variability and the least frequency in the west. Mean annual precipitation (1951-80) throughout the study area ranges from $32 \mathrm{in}$. in the east to $10 \mathrm{in}$. in the west (Riggio and others, 1987, fig. 11). Winter is the driest of the four seasons. During the winter of 1974-75, conditions were moderately wet ( 1.8 to $2.0 \mathrm{in}$.) in the 


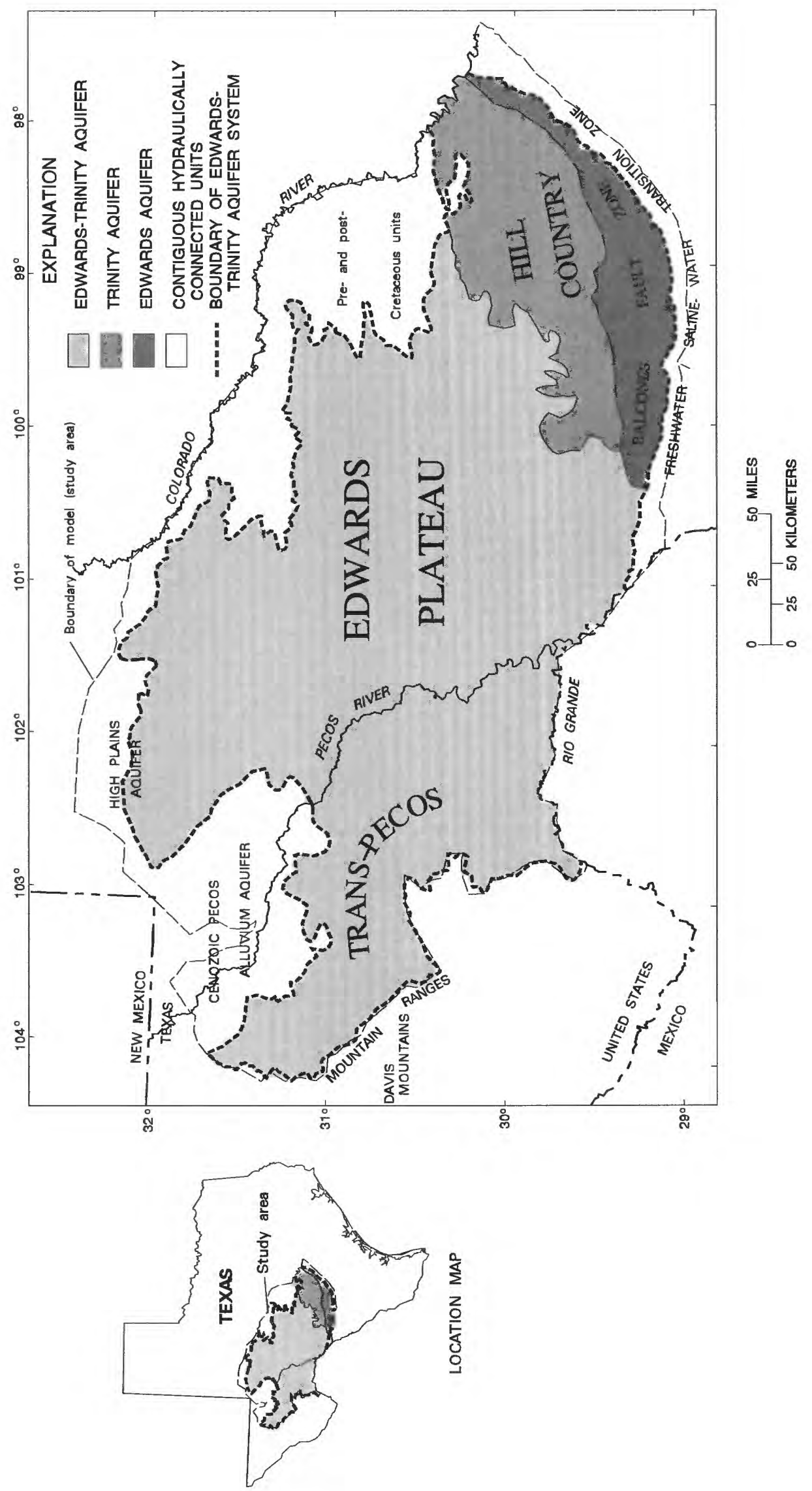

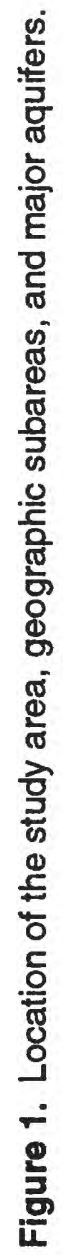




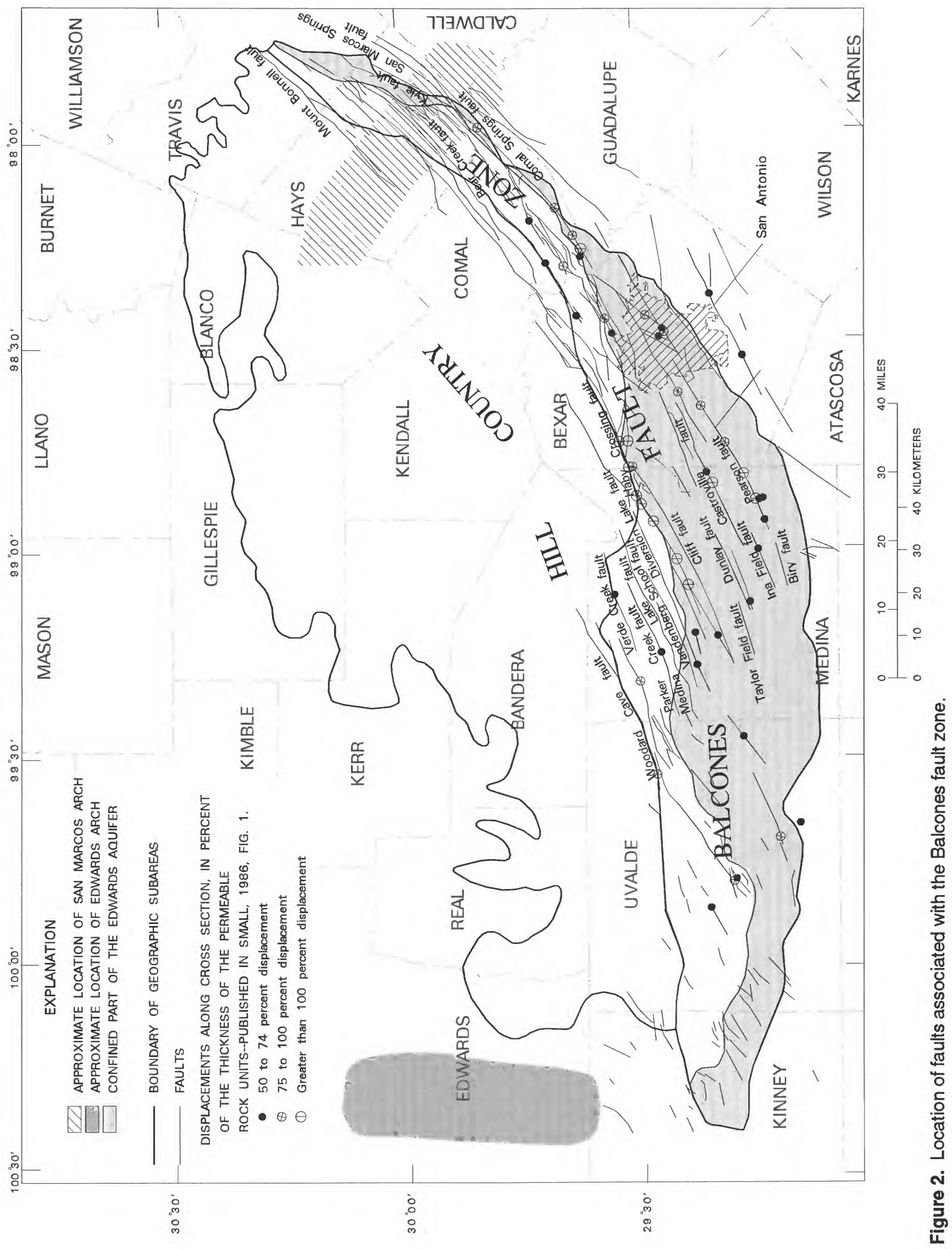


Trans-Pecos subarea and near normal (5.0 to 8.0 in.) in the other subareas of the study area (Karl and Knight, 1985). Mean annual temperature (1941-70) ranges from $69^{\circ} \mathrm{F}$ along the Balcones fault zone in the east to $63^{\circ} \mathrm{F}$ at the western edge of the Trans-Pecos (Texas Water Development Board, written commun., 1974).

Over most of the arid and semiarid subareas of the Trans-Pecos, Edwards Plateau, and Hill Country, soil development is poor and soil thickness is often less than $1 \mathrm{ft}$. In the Trans-Pecos, soils are clay loams over rough, stony terrain vegetated by desert shrubs. In the Edwards Plateau, soils tend to be calcareous stony clays vegetated by desert shrubs in the west; and juniper, oak, and mesquite in the east. The Hill Country has soils and vegetation similar to those of the Edwards Plateau. In the northeastern part of the Balcones fault zone, soils are calcareous clays, clayey loams, and sandy loams with some prairie vegetation. In the southwestern part of the Balcones fault zone, west of San Antonio, the vegetation changes to the more arid vegetation of juniper, oak, and mesquite (Kier and others, 1977).

\section{Acknowledgments}

The authors are grateful to Morris L. Maslia, formerly of the U.S. Geological Survey, Doraville, Georgia, for providing computer programs for aiding finite-element mesh generation and optimizing the node numbering of the mesh. The authors also thank the Texas Natural Resources Information System and Texas Water Development Board for providing data for this study.

\section{HYDROGEOLOGIC SETTING}

\section{Hydrogeologic Units of the Edwards-Trinity Aquifer System and Contiguous Hydraulically Connected Units}

The major aquifers of the Edwards-Trinity system are located in rocks of Cretaceous age (Barker and others, 1994). The principal aquifers are named the Edwards-Trinity in the Trans-Pecos and Edwards Plateau, the Trinity in the Hill Country, and the Edwards in the Balcones fault zone (fig. 1). The Edwards-Trinity aquifer is predominantly composed of limestone and dolomite in its upper part and sand in its lower part. The
Trinity aquifer is composed of dolomitic limestone with interbedded sand, shale, and clay. The Edwards aquifer is an extensively fractured and solutioned limestone with horizontal beds of honeycombed limestone. Figure 3 shows the relation of hydrogeologic units and major aquifers and their stratigraphic ${ }^{1}$ equivalents, and indicates the hydrogeologic units that were simulated.

Throughout the Trans-Pecos and Edwards Plateau, the Edwards-Trinity aquifer is unconfined to semiconfined. The sediments forming the aquifer were lain in a marine environment in several depositional cycles and are horizontally bedded with many vertical joints. These vertical joints allow rainfall to percolate into the aquifer causing caverns to develop in some areas of the Edwards Plateau.

The Trinity aquifer in the Hill Country is most productive in the units of the Lower Glen Rose Limestone, Hensel Sand, Cow Creek Limestone, and Hosston and Sligo Formations. Rocks of the Edwards Group (Rose, 1972) have mostly been eroded and only cap a few hills. The Upper Glen Rose also has been eroded exposing rocks of the Lower Glen Rose along the Blanco, Guadalupe, and Medina Rivers, and Cibolo Creek. The Hensel Sand is exposed along the Pedernales River (Ashworth, 1983). The Lower Glen Rose is known to be cavernous in the area of Cibolo Creek. Near the confluence of the Pedernales and Colorado Rivers near the northeastem limit of the Hill Country, lower Trinitian rocks (Glen Rose Limestone, Hensel Sand, and Cow Creek Limestone) are exposed along the river. In this area the most productive units are the Hosston and Sligo Formations.

The Edwards aquifer is unconfined in a narrow strip where rocks of the Edwards Group (Rose, 1972) crop out along the southem edge of the Edwards Plateau and the Hill Country. Most of this aquifer is confined downdip from the outcrop (fig. 2). Rocks of this formation tend to be honeycombed, horizontally bedded, and more permeable than rocks of the adjacent Trinity aquifer. Dissolution of the rocks parallel to faults and joints has resulted in higher permeability along faults and joints than across faults and joints.

Throughout the study area, erosional unconformities result in contiguous hydraulically connected permeable units ranging in depositional age from Precambrian to Cenozoic. In the northwestern part of the

\footnotetext{
${ }^{1}$ The stratigraphic nomenclature used in this report was determined from several sources and does not necessarily follow usage of the U.S. Geological Survey.
} 


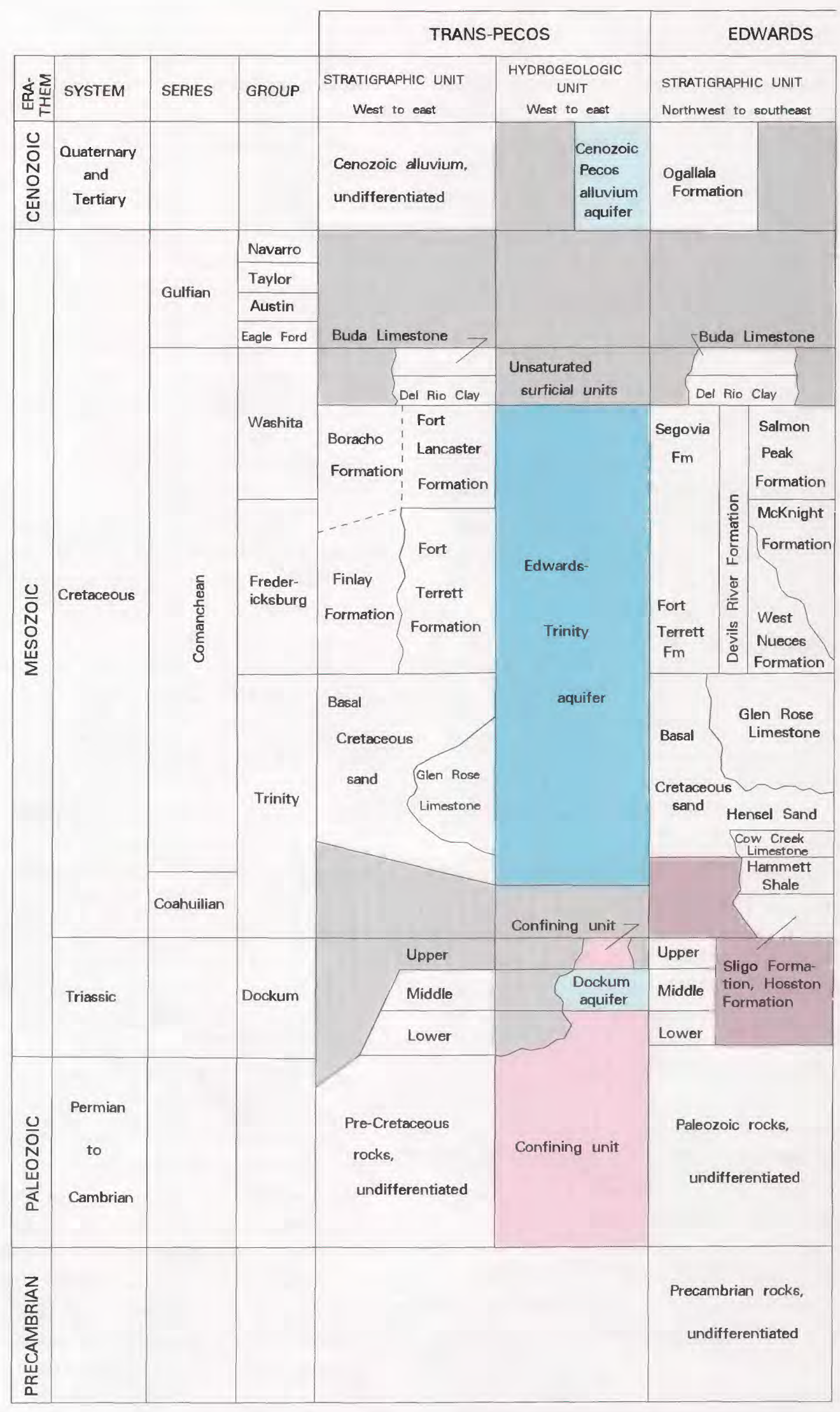

Figure 3. Relation of stratigraphic and hydrogeologic units. 


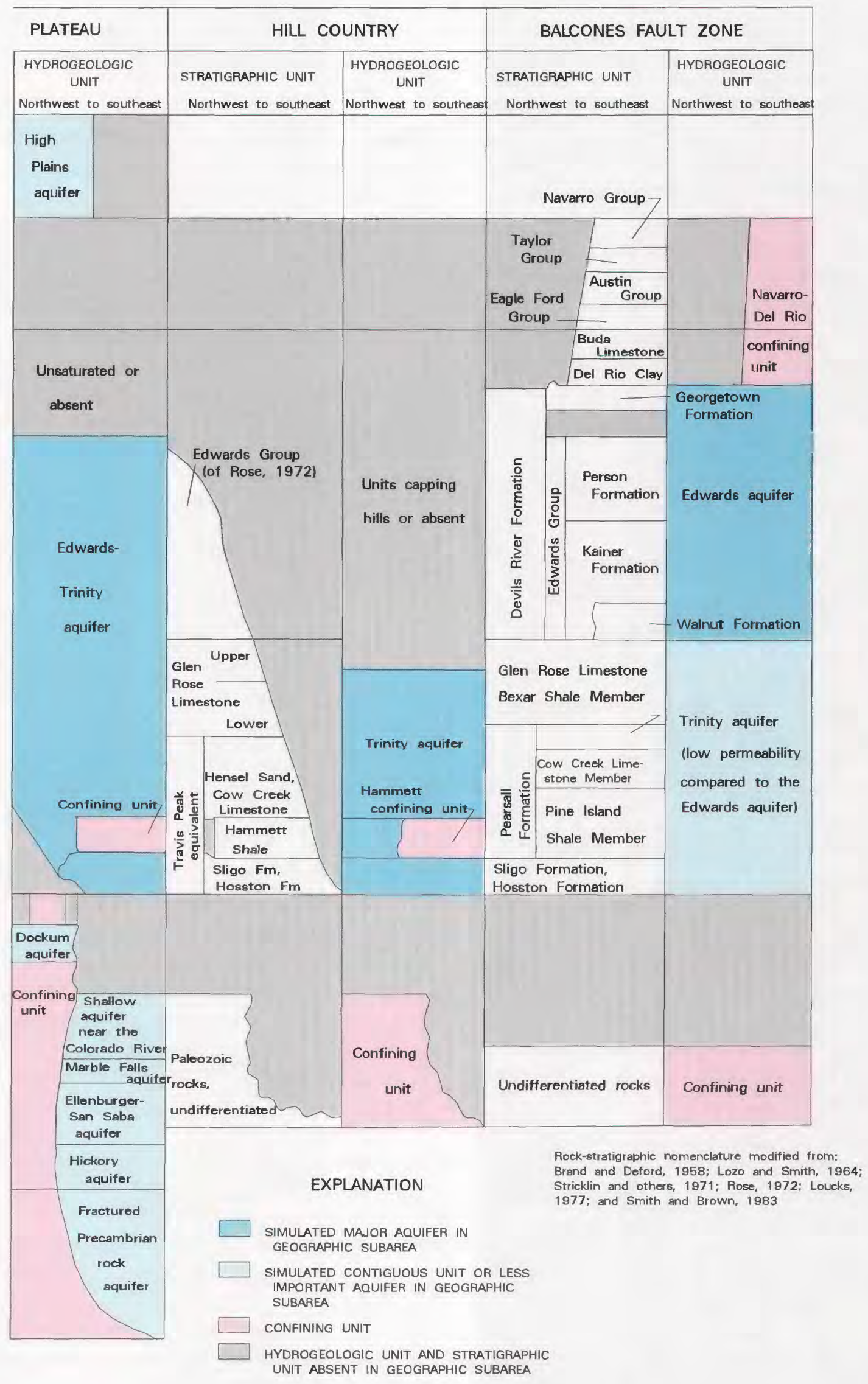


Trans-Pecos and Edwards Plateau, the Edwards-Trinity aquifer is overlain by and hydraulically connected to the Cenozoic Pecos alluvium aquifer near the Pecos River (Ogilbee and Wesselman, 1962, pl. 5-7; Rees and Buckner, 1980, fig. 3). Cretaceous rocks adjacent to the Pecos River have been removed by erosion so that the alluvial aquifer also is connected hydraulically to the Dockum aquifer (formerly called the Santa Rosa aquifer) of Triassic age (White, 1968, p. 20).

The High Plains aquifer (fig. 1) northwest of the Edwards Plateau is formed by sediments of Cenozoic age and overlies and is hydraulically connected to the basal Cretaceous sand of the Edwards-Trinity aquifer in the Edwards Plateau (Walker, 1979, p. 39; Ashworth and Christian, 1989, fig. 6).

Northeast of the Edwards Plateau, several stratigraphic units composed of sediments older and younger than the Edwards-Trinity aquifer form a shallow ground-water aquifer that drains toward the Colorado River and its tributaries (Lee, 1986, p. 9).

East of the Edwards Plateau, the Marble Falls aquifer, the Ellenburger-San Saba aquifer, and the Hickory aquifer exist in older rocks of Palenzoic age. Precambrian metamorphic and igneous rocks composed of highly eroded, faulted, and fractured granite, gneiss, and schist also crop out in the region (Walker, 1979, table 2). These Precambrian rocks yield small quantities of water to domestic and stock wells (Mason, 1961, p. 16).

In general, throughout the Trans-Pecos and Edwards Plateau, the Cretaceous rocks form one continuous regional aquifer confined on the base by less permeable pre-Cretaceous rocks (Barker and Ardis, 1992). In the northern part of the Edwards Plateau, however, the confinement between the EdwardsTrinity aquifer and the Dockum aquifer has been eroded, and these older rocks are hydraulically connected to the Edwards-Trinity aquifer in the subsurface (Ashworth and Christian, 1989, fig. 6).

Two regionally mappable confining units exist within the Edwards-Trinity aquifer system (fig. 3 ). The Hammett confining unit, a shale layer that thickens to more than $100 \mathrm{ft}$ to the south, occurs mainly in the southem part of the Edwards Plateau and the Hill Country and separates the lower Trinitian rocks (Sligo and Hosston Formations) from the upper and middle Trinitian rocks (Glen Rose Limestone, Hensel Sand, and Cow Creek Limestone). The Navarro-Del Rio confining unit directly overlies the Edwards aquifer in the southern and eastem parts of the Balcones fault zone where the Edwards aquifer is an artesian aquifer.

\section{Geologic Structural Controls on Ground- Water Flow}

Faults and joints within the aquifer system have the greatest effect on ground-water flow. En echelon faulting in the Balcones fault zone created space for meteoric water to percolate through the carbonate rocks. Joints perpendicular to the faults also provide voids for water movement. As streams eroded through the rock in the Hill Country and Balcones fault zone, springs formed along the faults, joints, and bedding planes near the streambeds increasing the rate of dissolution of the rock. Over geologic time, this resulted in the numerous caverns and dissolution channels in the Edwards-Trinity aquifer system. More caverns form in the Edwards aquifer in the Balcones fault zone than in the Hill Country, and these caverns tend to be linear and parallel to the faults and joints (Wermund and others, 1978, fig. 12; Woodruff and others, 1989, figs. 6 and 14). Known springs within the Hill Country flow at less than $10 \mathrm{ft}^{3} / \mathrm{s}$, while several springs in the Balcones fault zone flow at greater than $100 \mathrm{ft}^{3} / \mathrm{s}$.

Faults, lineaments, and joints have been mapped extensively in the Hill Country and Balcones fault zone. However, little mapping of faults, lineaments, and joint orientations has been done in the Trans-Pecos and Edwards Plateau. Locations of faults within the Hill Country and Balcones fault zone are shown in figure 2 along with the location of the San Marcos arch.

The San Marcos arch is a pre-Cretaceous positive anticlinal feature. The Edwards-Trinity aquifer is thinner over the San Marcos arch (Ashworth, 1983, fig. 7). Localized highs in the pre-Cretaceous base of the aquifer system have the effect of reducing the saturated thickness of the more permeable Cretaceous rocks resulting in a restriction of ground-water movement (Barker and Ardis, 1992). The San Marcos arch has been associated with a ground-water divide in the Edwards aquifer that has been used as a boundary for local model studies of the Edwards aquifer (Klemt and others, 1979; Slade and others, 1985; Maclay and Land, 1988). The Edwards arch is another positive anticlinal feature in the pre-Cretaceous surface that resulted in less deposition of lower Trinitian rocks near the apex of the arch (fig. 2). 


\section{Hydraulic Characteristics}

The most important hydraulic characteristic of the aquifers within the study area is transmissivity. This property can range over several orders of magnitude for carbonate rocks in karstic terranes. Transmissivity is hydraulic conductivity multiplied by saturated thickness for clastic rock, but might not be associated with saturated thickness in carbonate rock where movement of water in the subsurface is related to dissolution channels rather than to porosity of the rock matrix. The most transmissive aquifer in the study area is the Edwards with values from 200,000 to more than 2 million $\mathrm{ft}^{2} / \mathrm{d}$ (Maclay and Small, 1986, p. 61). Transmissivities of the Trinity aquifer in the Hill Country ranged from 100 to $58,000 \mathrm{ft}^{2} / \mathrm{d}$. Little data exist for determining transmissivity in the Edwards Plateau; estimates ranged from 100 to $12,000 \mathrm{ft}^{2} / \mathrm{d}$. In the Trans-Pecos, transmissivities ranged from 100 to $39,000 \mathrm{ft}^{2} / \mathrm{d}$, but in general were more than those reported for the Hill Country or Edwards Plateau (R.A. Barker, U.S. Geological Survey, written commun., 1987). In general, transmissivity of an aquifer tends to increase with increasing saturated thickness.

Transmissivity data for some of the contiguous units were determined from saturated thickness or previous modeling studies. Saturated thickness of the Cenozoic Pecos alluvium ranged from 100 to more than $1,000 \mathrm{ft}$ (Ardis and Barker, 1993). Hydraulic conductivity of mixed sand and gravel ranges from 15 to 300 $\mathrm{ft} / \mathrm{d}$ (Bouwer, 1978, p. 38). Thus, transmissivity of the Cenozoic Pecos alluvium may range from 1,500 to over $300,000 \mathrm{ft}^{2} / \mathrm{d}$. Transmissivity ranged from 2,500 to $10,000 \mathrm{ft}^{2} / \mathrm{d}$ for the High Plains aquifer (Gutentag and others, 1984).

Anisotropy is another important property of rocks and is related to transmissivity. Anisotropy occurs when water can move through the rock matrix more easily in one direction than another. In most aquifers composed of flat-lying sedimentary rocks, water moves more easily in the horizontal plane than the vertical plane. This characteristic is one reason why ground-water flow through an aquifer can be approximated with two dimensions. The important anisotropic conditions in the Edwards-Trinity aquifer system result from normal faults and vertical joints within the rocks that cause transmissivity to vary with direction in the horizontal plane.

The direction of anisotropy within the rocks is determined by the known fault, joint, and lineament patterns with maximum transmissivity aligned with the faults. Straight cavern chambers often develop along faults and joints. Studies of lineaments, faults, and joints in the Edwards aquifer near Austin (Woodruff and others, 1989, figs. 6 and 14) indicate that one-third of the straight-cavem chambers are aligned in the same direction as three-fourths of the faults. In the Austin area the strike of the faults ranges from N. $30^{\circ} \mathrm{E}$. to $\mathrm{N}$. $60^{\circ} \mathrm{E}$. Vertical displacement along en echelon faults places rocks of high permeability horizontally adjacent to rocks of lower permeability, resulting in a barrier to flow across the fault (Maclay and Land, 1988, fig. 11).

The ratio of the maximum to minimum transmissivity is difficult to determine. Where the displacement of a fault is greater than the thickness of the permeable rock unit and places this unit horizontally adjacent to a confining unit or less permeable aquifer unit, the ratio may be 1 to 0 , as simulated by Maclay and Land (1988, fig. 20). Figure 2 shows the displacement, in percent of thickness, of the Edwards aquifer along faults in the San Antonio part of the Edwards aquifer as determined by Ted Small (U.S. Geological Survey, written commun., 1989) at points where geologic sections published in Small (1986) intersect faults.

Vertical leakage through confining beds between the aquifer and streams or springs requires the definition of a hydraulic term related to vertical hydraulic conductivity. This term is the leakage coefficient and is defined as the area of the leakage to the stream or spring multiplied by the vertical hydraulic conductivity of the intervening confinement divided by the thickness of the confining bed. In general, little data exist for either the thickness of the confining bed or the vertical hydraulic conductivity of the confining bed. The leakage coefficient can be estimated, however, from stream reach length, stream width, and infiltration rates of soils near the river (these data are obtained from county soil surveys by the U.S. Department of Agriculture, Soil Conservation Service.)

The storage coefficient is another hydraulic property and is a measure of the volume of water an aquifer releases or takes into storage per unit surface area per unit change in water level. Few values of storage coefficient have been determined from aquifer tests. In the Edwards Plateau, four aquifer tests in the basal Cretaceous sand resulted in an average storage coefficient of 0.074 (Walker, 1979, p. 73 ), which is in the range of values for unconfined aquifers. A value for the storage coefficient has not been determined for carbonate rocks in the Trans-Pecos and Edwards Plateau. In the Hill 
Country, the storage coefficient determined from six measurements in lower Trinitian rocks (Sligo, Hosston, Cow Creek, and Hensel), ranged from $2 \times 10^{-5}$ to $7.4 \times 10^{-4}$ (Ashworth, 1983, table 3), typical of artesian aquifers. For the Edwards aquifer in the Balcones fault zone, the specific yield for the unconfined zone was estimated to be 0.03 , and for the confined zone, the storage coefficient ranged from $1 \times 10^{-5}$ to $1 \times 10^{-4}$ (Maclay and Small, 1986, p. 68-69).

Another method of estimating the amount of water that can go in or out of storage for the Edwards aquifer is by plotting the cumulative annual change in storage for each year versus the average annual water level in key wells and fitting a curve to the data (Garza, 1966, fig. 9). The slope of the curve indicates the volume of water released from or taken into storage per unit change in water level. In San Antonio, different volumes of water can go in or out of storage depending on the average water level: For low water levels in the index well, 50,000 acre- $\mathrm{ft} / \mathrm{ft}$ can go in or out of storage; for average water levels, 45,000 acre-ft/ft; and for high water levels, 40,000 acre- $\mathrm{ft} / \mathrm{ft}$. This method does not provide a storage-coefficient value because the area over which the water comes out of storage was not determined. The maximum possible area is that of the entire Balcones fault zone, about $3,000 \mathrm{mi}^{2}$, which results in a minimum estimate of storage coefficient, 0.02 , for the Edwards aquifer.

\section{Regional Flow}

The potentiometric surface of the EdwardsTrinity aquifer system was mapped for winter 1974-75 (fig. 4) and the earliest measurements (1915-69) were mapped to represent predevelopment conditions (fig. 5). In an isotropic aquifer (an aquifer in which hydraulic properties are independent of direction) ground-water movement is perpendicular to the potentiometric contours. The potentiometric maps shown in figures 4 and 5 indicate the potential for ground-water flow in the Edwards-Trinity aquifer system and hydraulically connected units. In the Balcones fault zone, where anisotropy strongly influences ground-water flow, flow is not perpendicular to the contours, but is downgradient. The two maps are similar over most of the area, and regional ground-water movement can be inferred from the two maps.

Regional ground-water movement was toward the perennial streams over the unconfined part of the system in the Trans-Pecos, Edwards Plateau, and Hill Country. In these areas the potentiometric surface tends to follow the topography. The hydraulic gradient is steepest at the western edge of the Trans-Pecos near the mountains and flattest at the center of the Edwards Plateau (figs. 4 and 5). The surface varies from slightly above land surface near springs, to near land surface adjacent to some streams, and to more than $800 \mathrm{ft}$ below land surface near the mountains. In the Balcones fault zone, anisotropy caused by dissolution of the rocks presents less resistance to flow along the faults. The gradient from west to east is small, but the flow in this direction is large. Head gradients shown on more detailed potentiometric maps of the Edwards aquifer (Garza, 1962, pls. 1-2; Maclay and Small, 1986, fig. 23) indicate flow from southwest to northeast along the strike of the faults.

The potentiometric surface can indicate areas of recharge, discharge, and changes in aquifer characteristics. In general, highs in the surface indicate areas of recharge and lows in the surface indicate areas of discharge. Recharge is indicated along the edge of the aquifer adjacent to the mountains in the Trans-Pecos. In addition, water appears to enter the Edwards-Trinity aquifer laterally from the High Plains aquifer. Areas where hydraulic gradients anomalously steepen could indicate a reduction in aquifer transmissivity. Such areas are not apparent on the potentiometric maps (figs. 4 and 5).

The perennial streams serve not only as surfacewater drains, but also as drains of the regional groundwater flow system in the Trans-Pecos, Edwards Plateau, and Hill Country. The Colorado River, Pecos River, and the Rio Grande drain the Edwards-Trinity aquifer system and the hydraulically connected units as evidenced by the hydraulic gradient toward these rivers. There are more streams in the Hill Country than in the Trans-Pecos and Edwards Plateau. However, these streams are not regional drains of the aquifer system. The potentiometric surface indicates that ground-water discharge to the streams in the Hill Country is more localized, with the regional gradient from northwest to southeast.

Measurable differences between the postdevelopment and historical potentiometric surfaces occur in the Trans-Pecos and northwestem part of the Edwards Plateau. The largest declines in the Trans-Pecos are in Reeves County and are greater than $300 \mathrm{ft}$. Declines in the Edwards Plateau are greatest in Glasscock County and are greater than $100 \mathrm{ft}$. These are the most arid 


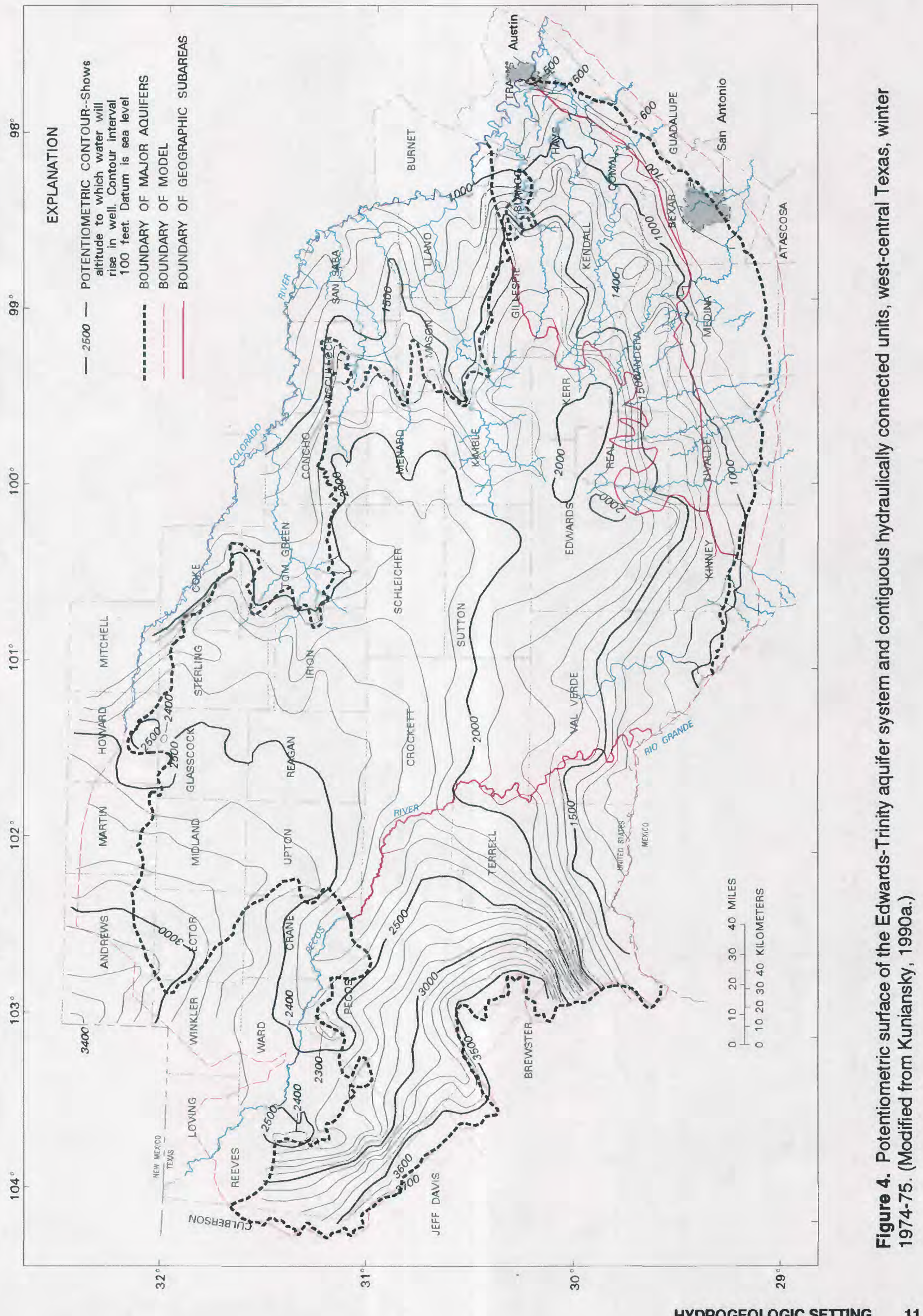




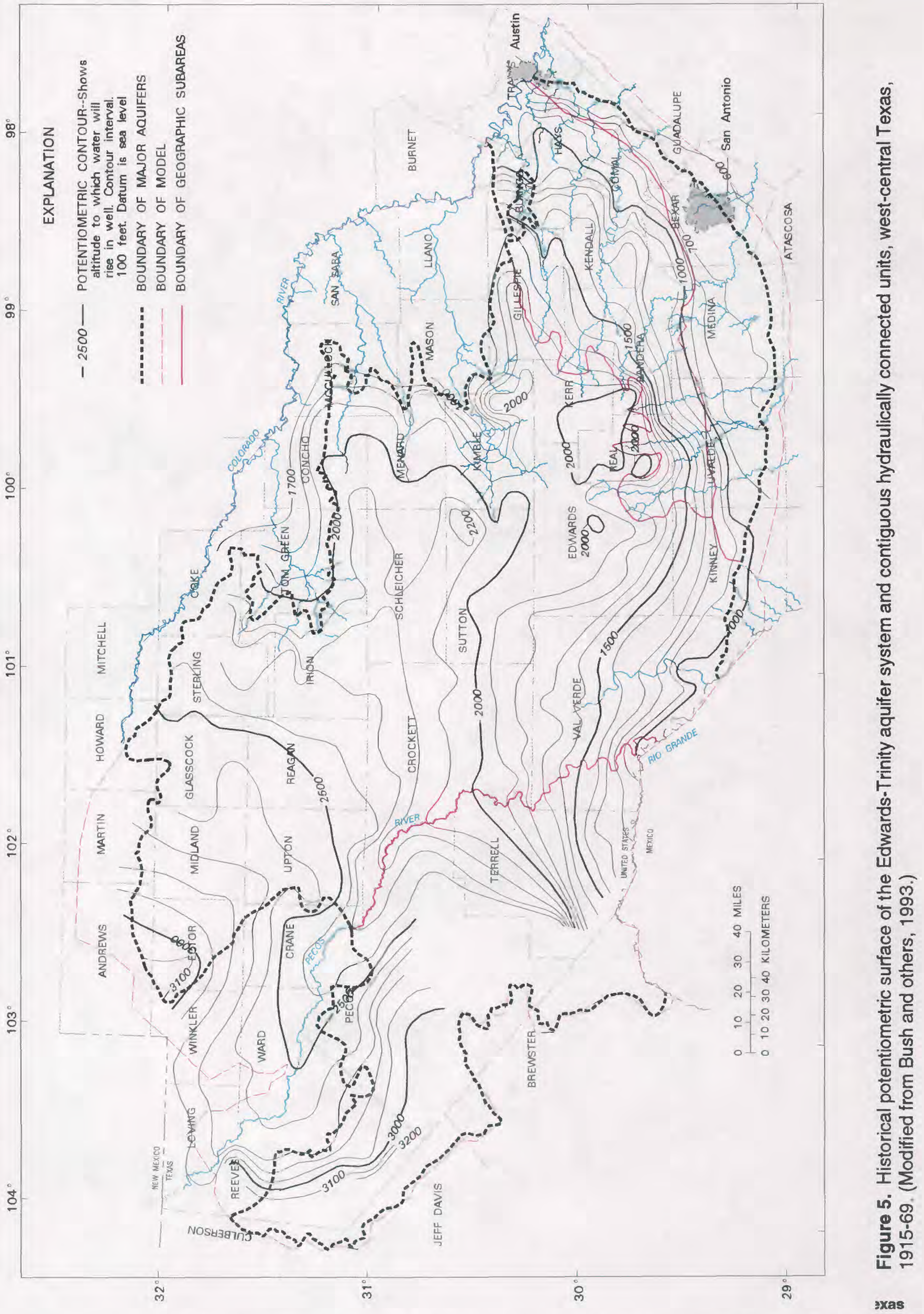


parts of the study area. Ground-water use, mainly for irrigation, has reversed the natural gradient to the Pecos River. Declines in water levels have resulted in reduced discharge at many springs. Most of the springs in Pecos County have ceased flowing because of the irrigation pumpage (Brune, 1975, fig. 18, p. 56-59).

\section{Recharge and Discharge}

Recharge to the ground-water flow system occurs when precipitation is greater than evapotranspiration and the soil zone is saturated. Methods of estimating evapotranspiration from climatic data are not refined. The best methods require sophisticated datacollection equipment. In the San Antonio area of the Edwards aquifer, more than 20 years has been spent on refining the methods of estimating recharge (Puente, $1975,1976,1978)$. Estimated recharge to the Edwards aquifer in the San Antonio area was 339,838 acre-ft during winter 1974-75 (G.B. Ozuna, U.S. Geological Survey, written commun., 1986). In the remainder of the eastem part of the study area, base flow determined by hydrograph separation was used as the estimate of maximum recharge over gaged areas (Kuniansky, 1989).

Recharge for all the aquifers in Texas was estimated by Muller and Price (1979). For much of the study area, their estimates were based on historical springflow. Their estimate for the Edwards-Trinity aquifer is $776,000 \mathrm{acre}-\mathrm{ft} / \mathrm{yr}(0.5 \mathrm{in} / \mathrm{yr})$. Values for recharge to parts of the Edwards-Trinity aquifer ranged from 0.48 to $0.88 \mathrm{in} / \mathrm{yr}$. Recharge to the High Plains aquifer was estimated to be $0.175 \mathrm{in} / \mathrm{yr}$. The only other aquifer in the study area for which an annual areal rate could be determined was the Hickory aquifer, which has an estimated recharge rate of $2.6 \mathrm{in} / \mathrm{yr}$ (D.A. Muller, Texas Water Development Board, oral commun., 1989).

In the Trans-Pecos and western part of the Edwards Plateau, ground-water withdrawals for irrigation, livestock, and rural domestic use divert ground water that normally would discharge to streams. Total streamflow or streamflow increase between gages was less than $0.5 \mathrm{in} / \mathrm{yr}$ based on the capture area that feeds this part of the stream. Base flow was less than 0.1 in/yr for December 1974 through March 1977 (Kuniansky, 1989). Ground-water withdrawals were an order of magnitude greater than the increase in streamflow. Another estimate of recharge in these areas is long-term average annual pumpage (assuming the system reached equilibrium or steady-state condition of recharge equal to discharge with a negligible change in storage). When the average rate of pumpage is distributed areally in a pattern similar to average annual precipitation, the range is 0.15 to $0.60 \mathrm{in} / \mathrm{yr}$, similar to the estimate of $0.5 \mathrm{in} / \mathrm{yr}$ by Muller and Price (1979).

Additional recharge has been documented in the Trans-Pecos where surface water is used for irrigation along the Pecos River. A study by the Pecos River Joint Investigation concluded that 30 to 72 percent of the surface water in canals was lost to evaporation and to percolation into the Cenozoic Pecos alluvium aquifer, and about 20 percent of irrigation water returned to the aquifer (Ashworth, 1990, p. 12).

Recharge to the Edwards aquifer occurs areally between streams and directly along streambeds on the outcropped rocks of the Edwards Group along a narrow strip at the edge of the Hill Country and Balcones fault zone (Maclay and Small, 1986, fig. 1). Examination of streamflow records indicates loss of surface water to the Edwards aquifer. Streams crossing the Edwards group become intermittent in the Balcones fault zone (fig. 1).

Numerous springs are natural discharge points for the flow system (pl. 1). The largest springs are along the southern edge of the Edwards Plateau and the Balcones fault zone. Some of the larger springs in this area are Goodenough (now submerged beneath water in the Amistad Reservoir), San Felipe, Las Moras, Leona, San Antonio, Hueco, Comal, San Marcos, and Barton. Goodenough, Comal, and San Marcos Springs discharged more than $100 \mathrm{ft}^{3} / \mathrm{s}$ (Brune, 1975). Discharge for Barton, Comal, and San Marcos Springs is measured by gaging the streams just downstream of the springs. The average discharge at Barton Springs is 56 $\mathrm{ft}^{3} / \mathrm{s}$ (water years 1918, 1979-89; Buckner and others, 1989) and was estimated to be $97 \mathrm{ft}^{3} / \mathrm{s}$ for winter 197475 (Slade and others, 1986, table 6). The average discharge of Comal Springs is $294 \mathrm{ft}^{3} / \mathrm{s}$ (water years 193389; Buckner and others, 1989) and discharge for winter $1974-75$ was $415 \mathrm{ft}^{3} / \mathrm{s}$ (U.S. Geological Survey, 1975). The average discharge of San Marcos Springs is 166 $\mathrm{ft}^{3} / \mathrm{s}$ (water years 1957-89; Buckner and others, 1989) and discharge for winter 1974-75 was $241 \mathrm{ft}^{3} / \mathrm{s}$ (U.S. Geological Survey, 1975). The remaining springs generally discharge less than $100 \mathrm{ft}^{3} / \mathrm{s}$. San Antonio and Hueco Springs do not flow during drought conditions, but can have discharge greater than $100 \mathrm{ft}^{3} / \mathrm{s}$ after wet periods or high-intensity storms, which indicates more 
localized recharge areas than the continually discharging springs. Contours on the potentiometric surface maps (figs. 4 and 5) show little of this natural discharge because of the large transmissivity and the regional anisotropy of the Edwards aquifer.

Prior to ground-water development in the TransPecos; Phantom Lake, San Solomon, Leon, and Comanche Springs flowed at rates from 10 to $100 \mathrm{ft}^{3} / \mathrm{s}$. Brune (1975) compares the flow of known springs in 1500 to springs in 1973. Of these four springs, only Phantom Lake and San Solomon currently flow at rates generally less than $10 \mathrm{ft}^{3} / \mathrm{s}$. Six springs with predevelopment flows from 1 to $10 \mathrm{ft}^{3} / \mathrm{s}$ also have ceased flowing (Brune, 1975, fig. 18).

All withdrawal data is estimated throughout the study area. There is no requirement for reporting or metering ground-water withdrawals. The Texas Water Development Board estimates withdrawals every 5 years. For the Edwards aquifer, the U.S. Geological Survey estimates withdrawals each year as part of its cooperative program with the Edwards Underground Water District. Pumpage may be in error by as much as 20 percent for the Edwards aquifer (Fisher, 1990, p. 9). Livestock and rural domestic withdrawal rates were estimated for winter 1974-75, based on populations of livestock and people and totaled by county. Industrial and municipal average withdrawal rates were computed for December 1974 through February 1975. Irrigation withdrawals of ground water were assumed to be located at the centers of irrigated fields (D.L. Lurry, U.S. Geological Survey, written commun., 1989). The maps of irrigated fields were obtained from the Texas Water Development Board. Industrial and municipal wells also were located (D.J. Pavlicek, U.S. Geological Survey, written commun., 1988). The locations of municipal, industrial, and irrigation withdrawals are shown in figure 6.

The largest municipal and industrial groundwater use is in the San Antonio area, where about 270,000 acre- $\mathrm{ft}$ of water were pumped in 1974, but because of the large transmissivity and the regional anisotropy of the Edwards aquifer, no cone of depression appears on the regional map (fig. 4). Near the Pecos River, there are two cones of depression. Irrigation withdrawals in this area were about 420,000 acre$\mathrm{ft}$ in 1974 (Texas Water Development Board, 1986).

In most of the Edwards-Trinity, southern High Plains, and alluvial aquifers in the Trans-Pecos and Edwards Plateau, the majority of ground-water with- drawals are for rural domestic, livestock, and irrigation use. In parts of these areas the volume of water withdrawn from the aquifers exceeded the amount of water recharging the aquifers as evidenced by long-term decline in water levels (fig. 7; Ogilbee and Wesselman, 1962, p. 39; Rees and Buckner, 1980, fig. 8; Ashworth and Christian, 1989, fig. 11).

\section{Long-Term Water-Level Variations}

Long-term variations in water levels result from changes in storage, recharge, and (or) discharge from the aquifer. Hydrographs from 19 selected wells throughout the study area are shown in figure 7 , and a description of these wells is provided in table 1. Most of these hydrographs are from wells that are currently (1993) part of the water-level observation network or were historically part of the observation network of the Texas Water Development Board and the U.S. Geological Survey.

Of the five wells in the Edwards-Trinity aquifer, wells 1 and 2 are located in areas of large ground-water withdrawals for irrigation in Pecos and Glasscock Counties, respectively (see fig. 6). Well 1 is open to rocks of the Washita, Fredericksburg, and Trinity Groups. Well 2 is open to the basal Cretaceous sand of the Trinity Group (known as the Antlers sand, Texas Water Development Board nomenclature). Both wells are less than $300 \mathrm{ft}$ deep and are located where the aquifer is unconfined. The seasonal fluctuations in water level in these two wells are caused primarily by seasonal variation in irrigation withdrawals, but both wells show the effect of mining the aquifer because the seasonal high water level generally becomes lower with each passing year. As a result of its proximity to recharge from the Pecos River and from orographic rainfall from the mountains along the western boundary of the system, well 1 shows less of the effect of long-term mining than well 2 . Yearly water-level fluctuations are more than $100 \mathrm{ft}$ in well 1 and about $20 \mathrm{ft}$ in well 2.

Well 3 in the Edwards-Trinity aquifer, located away from major ground-water withdrawals, has seasonal water-level fluctuations less than $20 \mathrm{ft}$ over a 28year record. This well is less than $200 \mathrm{ft}$ deep and in the unconfined part of the Edwards-Trinity aquifer.

Wells 4 and 5 , in the southern part of the Edwards-Trinity aquifer, are drilled to depths greater than $500 \mathrm{ft}$ and open to Washita and Fredericksburg 


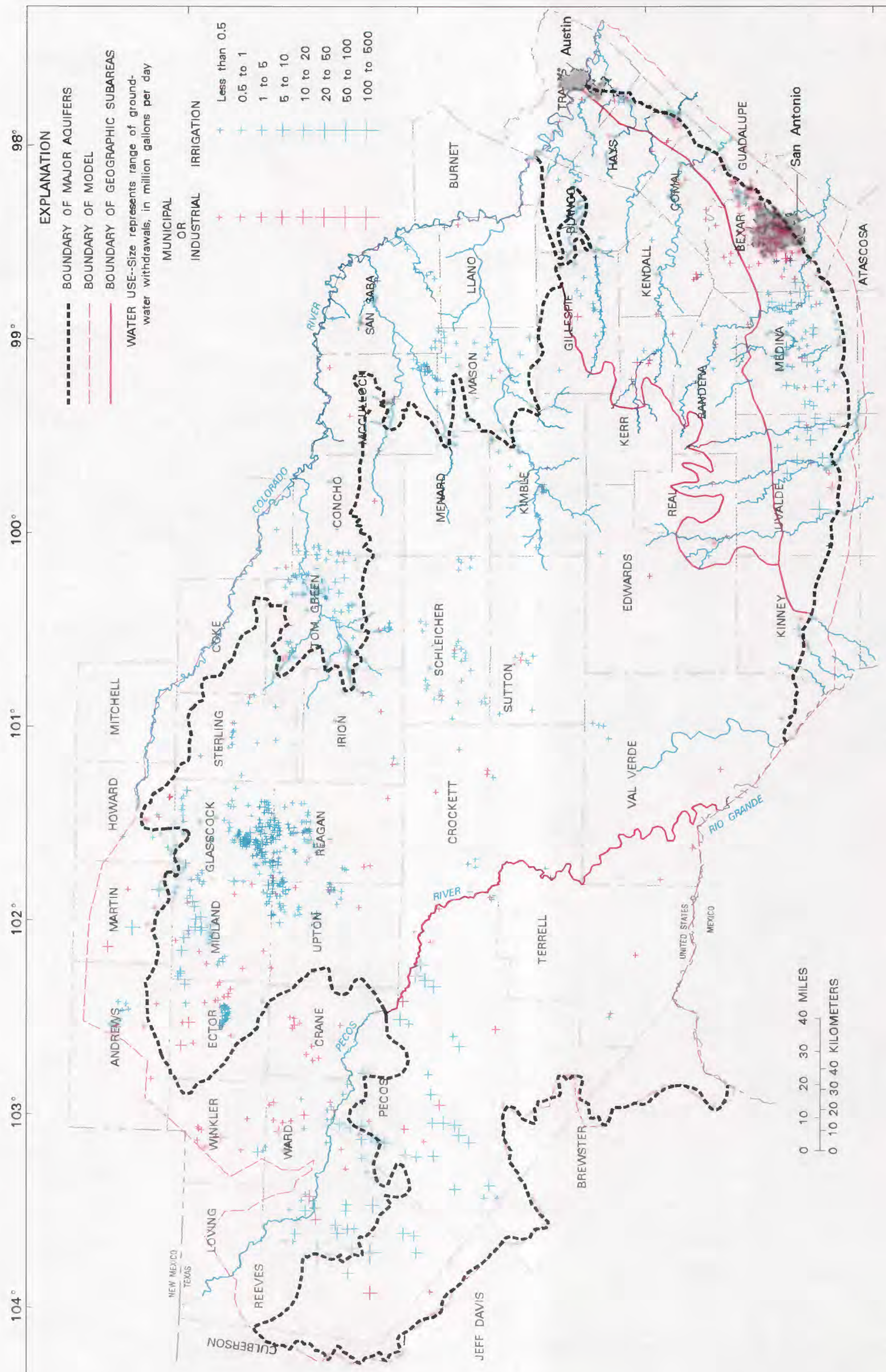

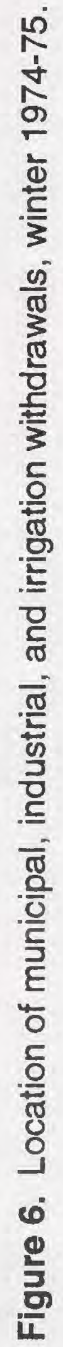


Edwards-Trinity aquifer, well 1

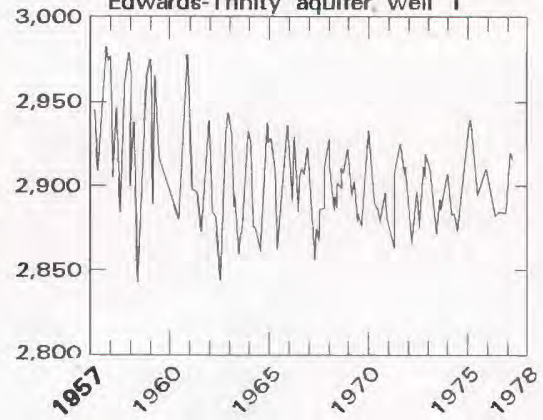

Edwards-Trinity aquifer, well 4

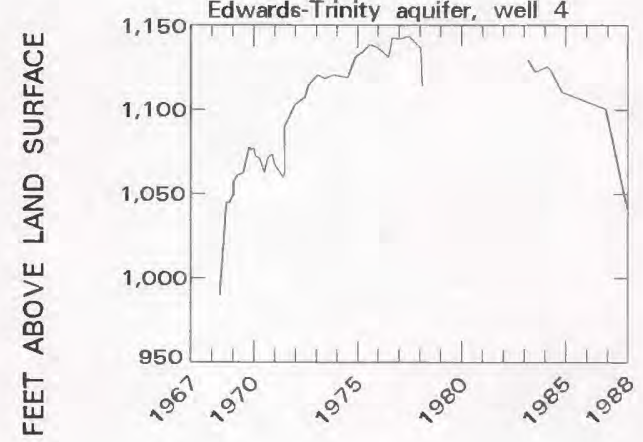

$\underline{Z}$
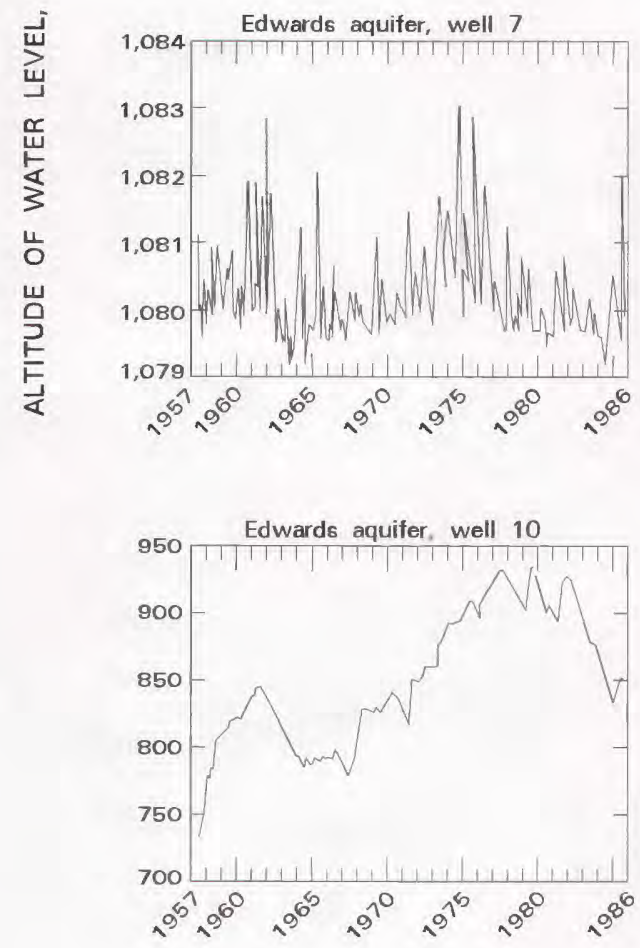

Edwards-Trinity aquifer, well 2
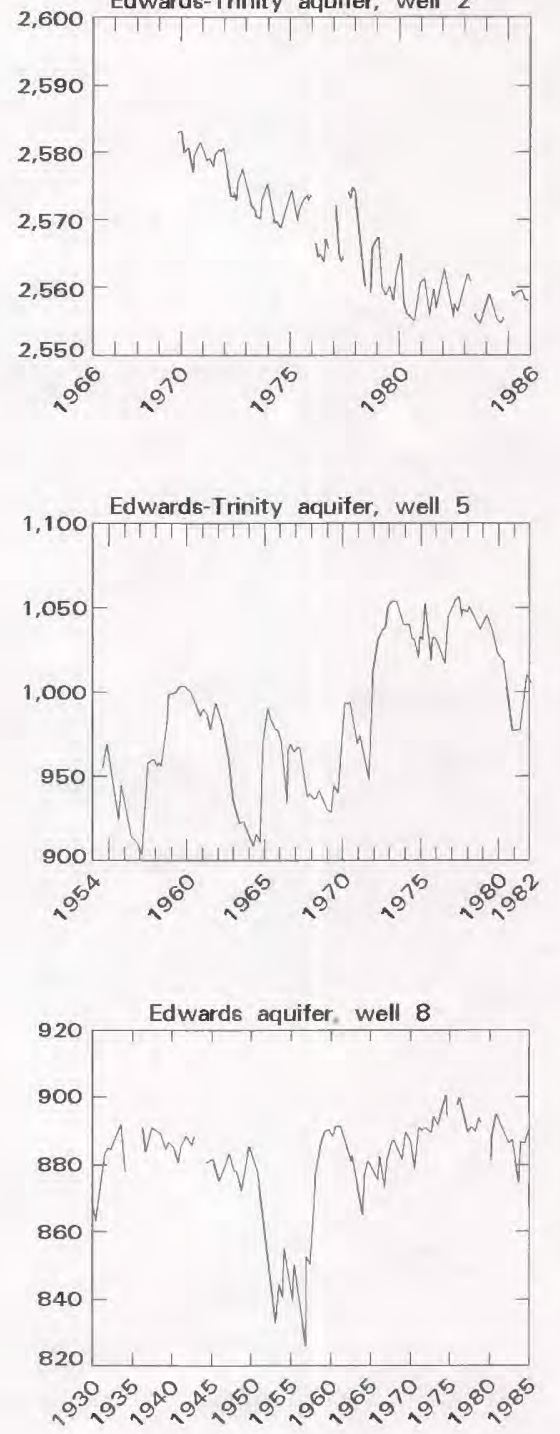

Edwards aquifer, well 11

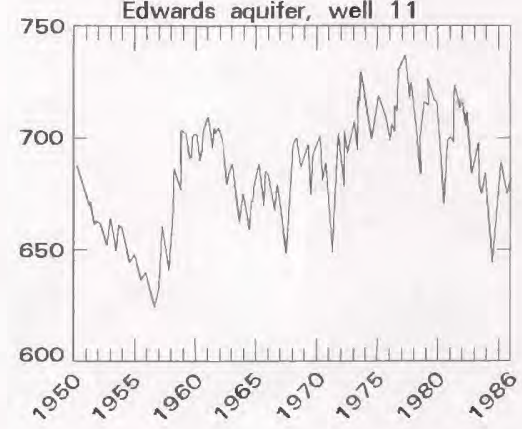

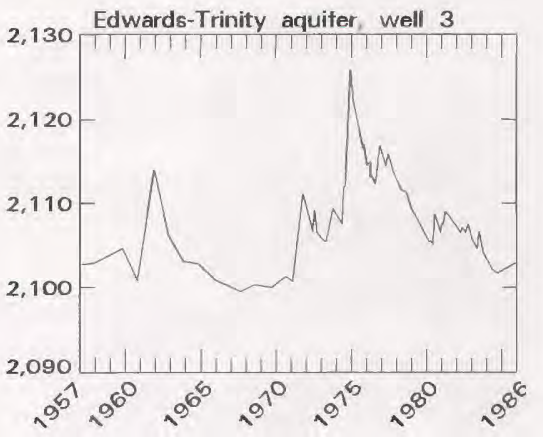

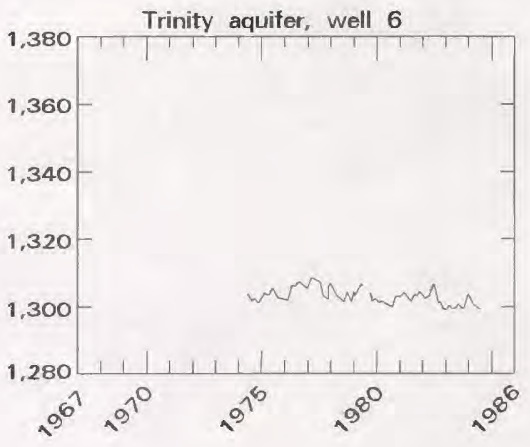

Edwards aquifer, well 9
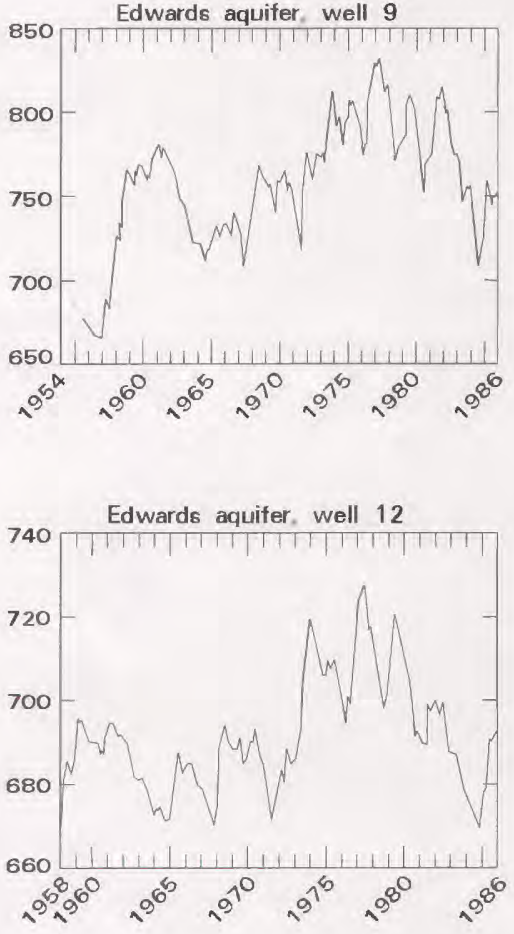

CALENDAR YEARS

Figure 7. Hydrograph from selected wells throughout the study area.

16 Simulations of Flow in the Edwards-Trinity Aquifer System and Contiguous Hydraulically Connected Units, West-Central Texas 

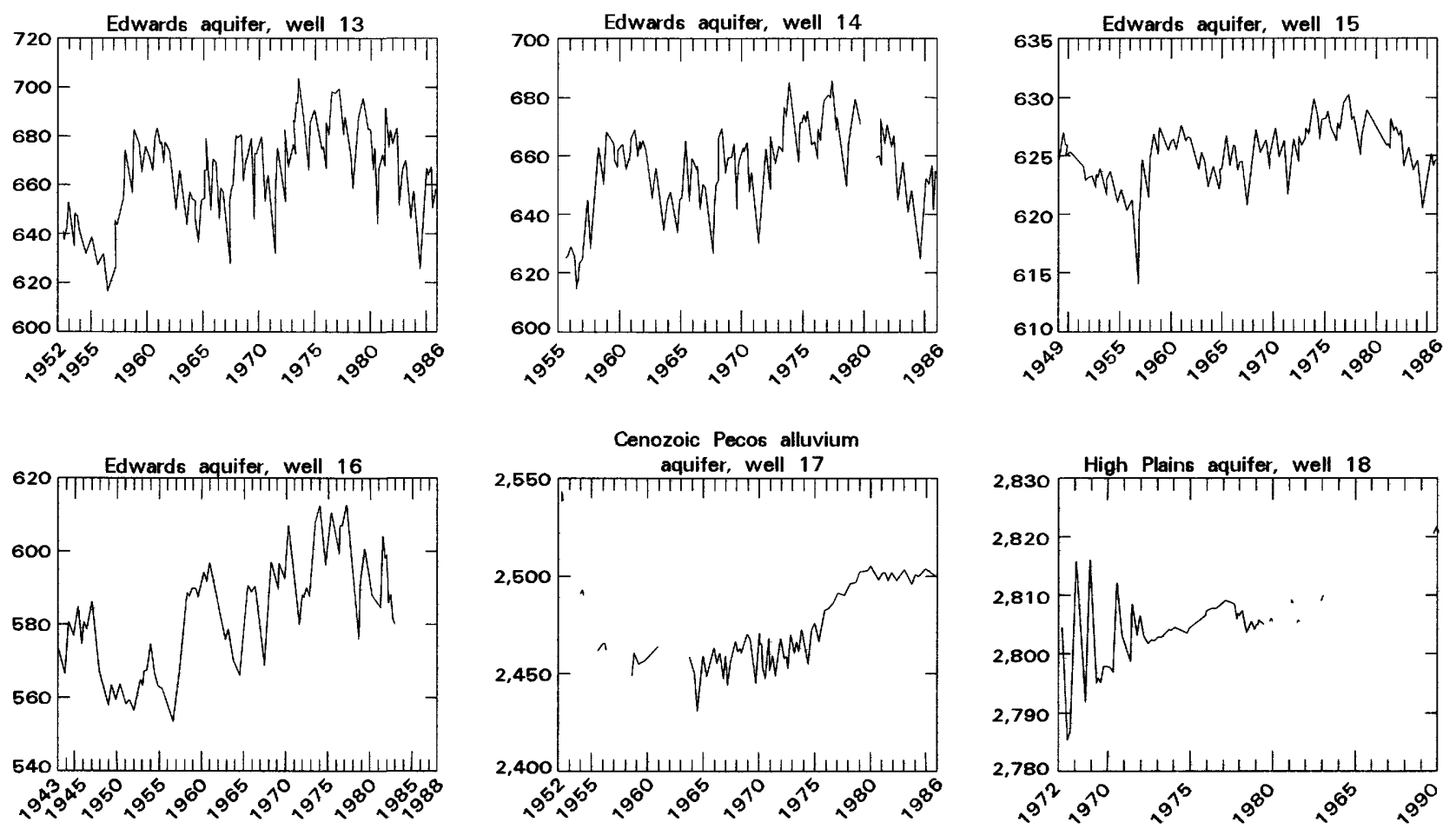

WELL LOCATION INDEX MAP

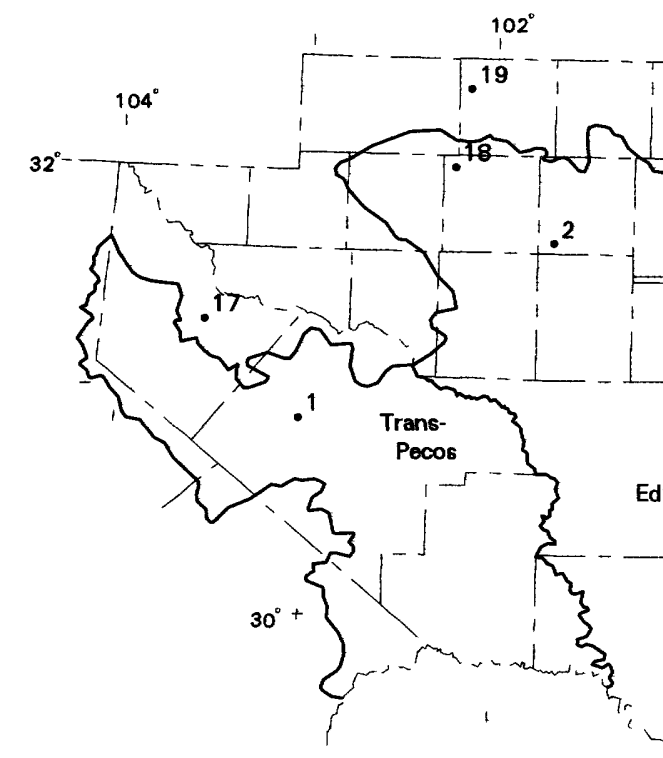

EXPLANATION

BOUNDARY OF GEOGRAPHIC SUBAREA

.3

WELL LOCATION AND REFERENCE NUMBER IN TABLE 1

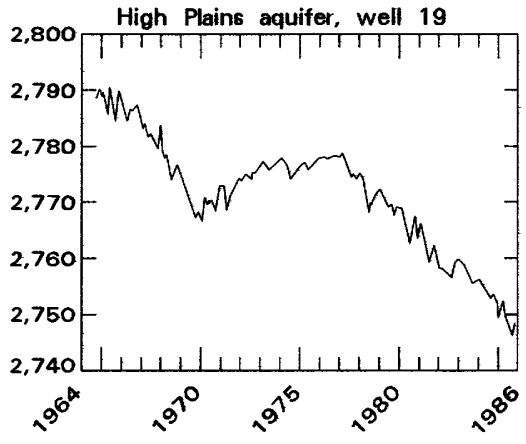


Table 1. Records of selected wells with hydrographs

\begin{tabular}{|c|c|c|c|c|c|c|}
\hline $\begin{array}{c}\text { Reference } \\
\text { number } \\
\text { (fig. 7) }\end{array}$ & $\begin{array}{c}\text { Well } \\
\text { number }\end{array}$ & County & Aquifer & $\begin{array}{l}\text { Well } \\
\text { depth } \\
\text { (feet) }\end{array}$ & $\begin{array}{l}\text { Altitude } \\
\text { of land } \\
\text { surface } \\
\text { (feet) }\end{array}$ & Remarks \\
\hline 1 & US-52-08-902 & Pecos & Edwards-Trinity & 290 & 3,012 & $\begin{array}{l}\text { Historical observation well } \\
\text { near irrigation. }\end{array}$ \\
\hline 2 & KL-44-19-505 & Glasscock & Edwards-Trinity & 160 & 2,708 & $\begin{array}{l}\text { Current observation well } \\
\text { near irrigation. }\end{array}$ \\
\hline 3 & WY-43-61-706 & Schleicher & Edwards-Trinity & 160 & 2,195 & Current observation well. \\
\hline 4 & YR-70-25-603 & Val Verde & Edwards-Trinity & 505 & 1,216 & $\begin{array}{l}\text { Artesian well used to } \\
\text { supply water for drilling } \\
\text { an oil test well. }\end{array}$ \\
\hline 5 & YR-70-42-205 & Val Verde & Edwards-Trinity & 750 & 1,057 & Current observation well. \\
\hline 6 & WR-69-19-401 & Real & Trinity & 820 & 1,595 & $\begin{array}{l}\text { Reported yield } 500 \text { gallons } \\
\text { per minute with } 175 \\
\text { feet of drawdown. } \\
\text { Unused irrigation well. }\end{array}$ \\
\hline 7 & YP-70-40-901 & Uvalde & Edwards & 140 & 1,122 & In outcrop of Edwards. \\
\hline 8 & YP-69-50-101 & Uvalde & Edwards & 100 & 951 & Stock well. \\
\hline 9 & YP-69-45-401 & Uvalde & Edwards & 1,476 & 954 & Observation well. \\
\hline 10 & TD-69-38-601 & Medina & Edwards & 538 & 1,008 & Observation well. \\
\hline 11 & TD-68-41-301 & Medina & Edwards & 710 & 757 & $\begin{array}{l}\text { Small amounts of sulfur } \\
\text { water enter from } \\
\text { Austin Chalk. }\end{array}$ \\
\hline 12 & AY-68-29-103 & Bexar & Edwards & 547 & 953 & $\begin{array}{l}\text { Development test draw- } \\
\text { down } 9.24 \text { feet pumping } \\
820 \text { gallons per minute } \\
\text { for } 1 \text { hour Sept. } 9,1942 .\end{array}$ \\
\hline 13 & AY-68-29-701 & Bexar & Edwards & 500 & 779 & Observation well. \\
\hline 14 & DX-68-30-208 & Comal & Edwards & 292 & 798 & Observation well. \\
\hline 15 & DX-68-23-302 & Comal & Edwards & 230 & 643 & Observation well. \\
\hline 16 & YD-58-58-301 & Travis & Edwards & 703 & 734 & Observation well. \\
\hline 17 & WD-46-44-501 & Reeves & $\begin{array}{l}\text { Cenozoic Pecos } \\
\text { alluvium }\end{array}$ & 627 & 2,640 & Observation well. \\
\hline 18 & TJ-27-63-705 & Midland & High Plains & 127 & 2,867 & $\begin{array}{l}\text { Unused public supply } \\
\text { well. }\end{array}$ \\
\hline 19 & SY-27-39-903 & Martin & High Plains & 182 & 2,895 & Observation well. \\
\hline
\end{tabular}


rocks. These two wells are in part of the EdwardsTrinity system that is semiconfined. Fluctuations in these hydrographs result from climatic events and the building and subsequent filling of the Amistad Reservoir, located near the confluence of the Devils River and Rio Grande (pl. 1). Impoundment of water in the Amistad Reservoir began in May 1968 and the dam was completed in November 1969. The conservation pool elevation is $240 \mathrm{ft}$ above the stilling basin below the dam. Amistad Reservoir filled between mid-1971 and the beginning of 1973 (International Boundary and Water Commission, 1985, p. 8). The hydrograph from well 5 shows long-term water-level variations of $100 \mathrm{ft}$ during 1955-68. Both hydrographs show the effect of the filling of the reservoir. The hydrograph for well 5 also shows the effect of the drought that occurred in the area, starting in 1951, that was finally broken by heavy rainfall in the spring of 1957 (Riggio and others, 1987, fig. 5). Well 4 is adjacent to the reservoir and is more affected by the impoundment of water in the reservoir. After the filling of the reservoir, long-term water-level variations were generally less than $50 \mathrm{ft}$ in this well.

There is one hydrograph from a well in the Trinity aquifer (well 6 in fig. 7). This well is drilled to a depth of $820 \mathrm{ft}$ into Trinitian rocks. Long-term variations in water levels are less than $10 \mathrm{ft}$, ranging from 285 to $295 \mathrm{ft}$ below land surface. Because this well is not located near large ground-water withdrawals, climate is the only influence on the water level.

Wells 7 through 16 are within the Edwards aquifer. Well 7 is the only well in the unconfined part of the Edwards aquifer. Seasonal fluctuations in well 7 are less than $5 \mathrm{ft}$. This well is not located near any large ground-water withdrawals and the fluctuations in water levels are rapid in response to storms. Because storage coefficients in unconfined parts of aquifers are three to five orders of magnitude greater than in confined parts of aquifers, the small fluctuations may represent large volumes of water going into or out of the aquifer.

The hydrographs with records between 1950 and 1960 (wells 8, 9, 11, 13, 15, and 16) indicate low water levels during the extended drought that started to affect the Edwards aquifer by 1951 and persisted through the winter of 1957 . Steady rainfall began in the spring of 1957 and water levels returned to normal by the end of 1957. Well 15, close to Comal Springs, did not have low water levels until late 1954, and Comal Springs did not cease flowing until late 1956, after 7 years of drought (Brune, 1975, p. 39). If the period of the drought is ignored, long-term water-level variations range from $30 \mathrm{ft}$ in well 8 to more than $150 \mathrm{ft}$ in well 10 . Well 10 has yearly variations of $75 \mathrm{ft}$. The hydrographs show that water levels dropped rapidly as a result of the drought and rose rapidly when rainfall resumed. While some of the wells are near large ground-water withdrawals, the large fluctuations in water levels in the confined part of the Edwards aquifer mainly result from rainfall variations.

Well 17 is screened in the Cenozoic Pecos alluvium aquifer adjacent to the Pecos River. The drop in water level that occurred between 1952 and 1959 is a result of irrigation withdrawals from the aquifer. Ground-water withdrawals peaked at 520,000 acre$\mathrm{ft} / \mathrm{yr}$ in 1953, then dropped to a range of 300,000 to 400,000 acre-ft/yr during 1958-1974 (Rees, 1987, table 1; Ashworth, 1990, fig. 9). According to the irrigation survey of 1979 , withdrawals were 109,000 acre-ft/yr (Texas Water Development Board, 1986). The hydrograph for well 17 indicates this withdrawal history.

Wells 18 and 19 are in the High Plains aquifer. Both wells are less than $200 \mathrm{ft}$ deep. The wells are affected by ground-water withdrawals; well 18 by irrigation withdrawals and well 19 by municipal and industrial withdrawals. The hydrograph for well 18 shows a rise in water level resulting from decreased agricultural development. The hydrograph for well 19 shows the effect of the mining of the High Plains aquifer. The seasonal fluctuations in each hydrograph result from both climatic events and withdrawals.

\section{SIMULATIONS OF GROUND-WATER FLOW}

\section{Model Development}

In developing a numerical model of an aquifer system, many simplifications are required in order to approximate the system. Flow through most porous media is three-dimensional, but most aquifers are several orders of magnitude thinner in the vertical dimension than in the horizontal dimension. In the case of the Edwards-Trinity aquifer system, the horizontal dimension is more than four orders of magnitude greater than the vertical dimension. Therefore, the flow can be approximated as two-dimensional and horizontal where the simulated water level is the vertically averaged water level within the aquifer. A generalized section showing the geologic units simulated as one layer is shown in figure 8 . 


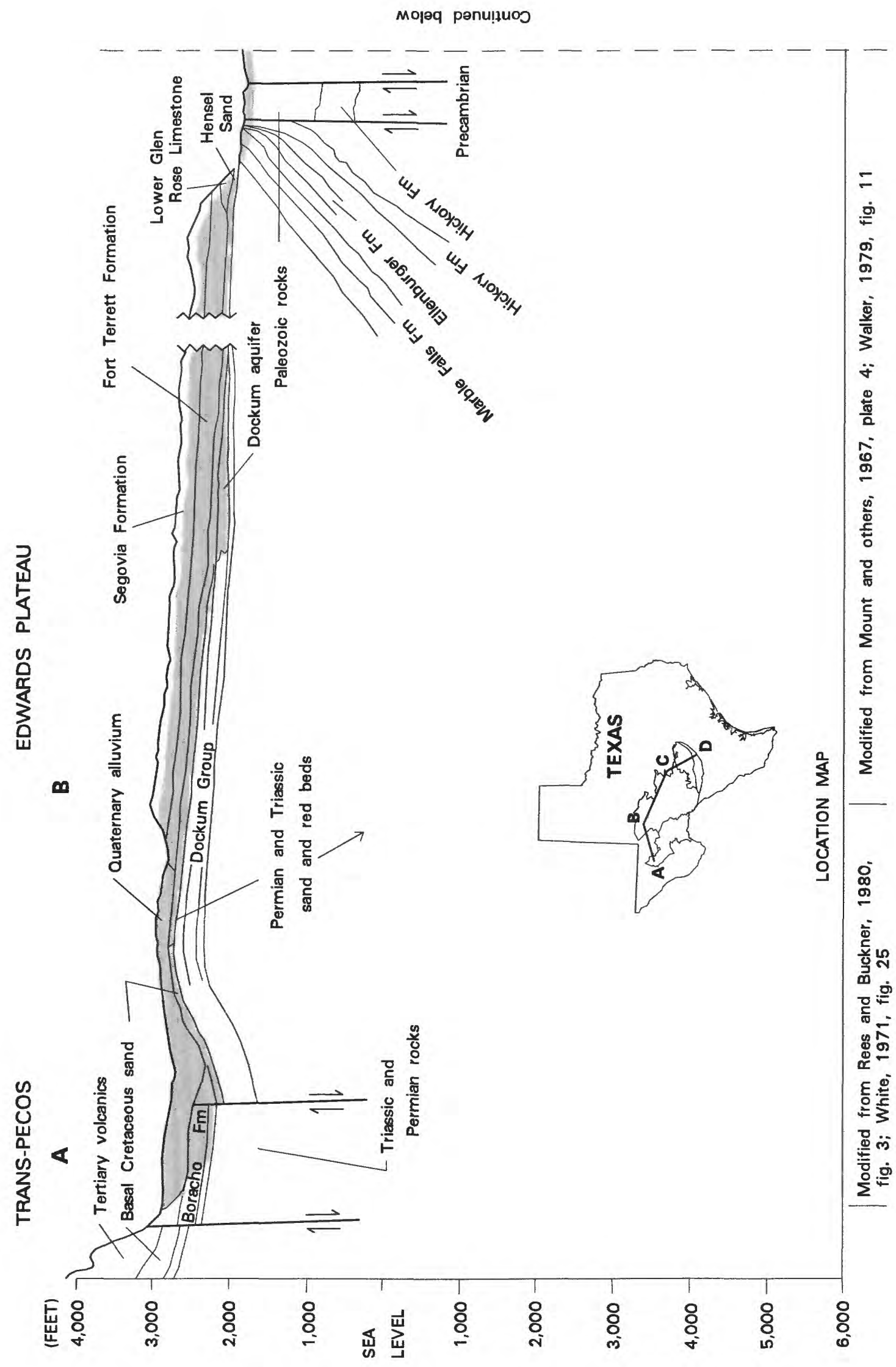

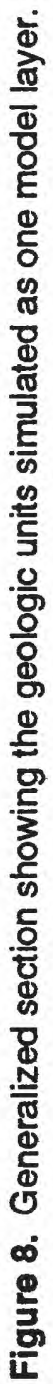




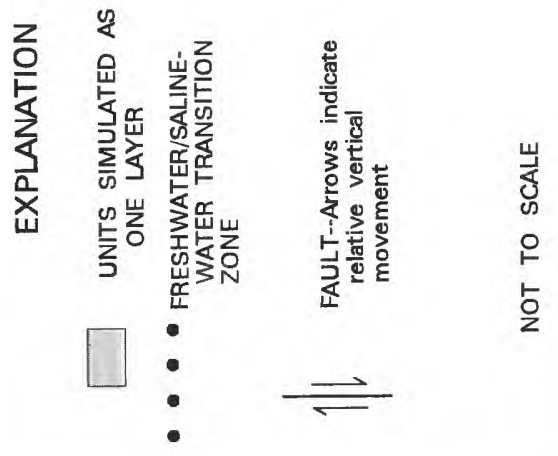

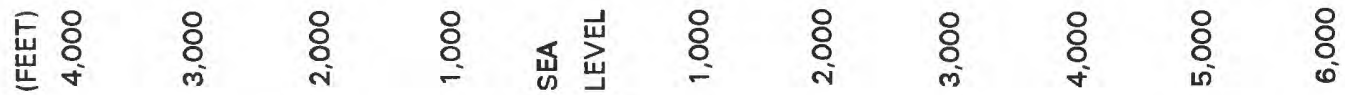

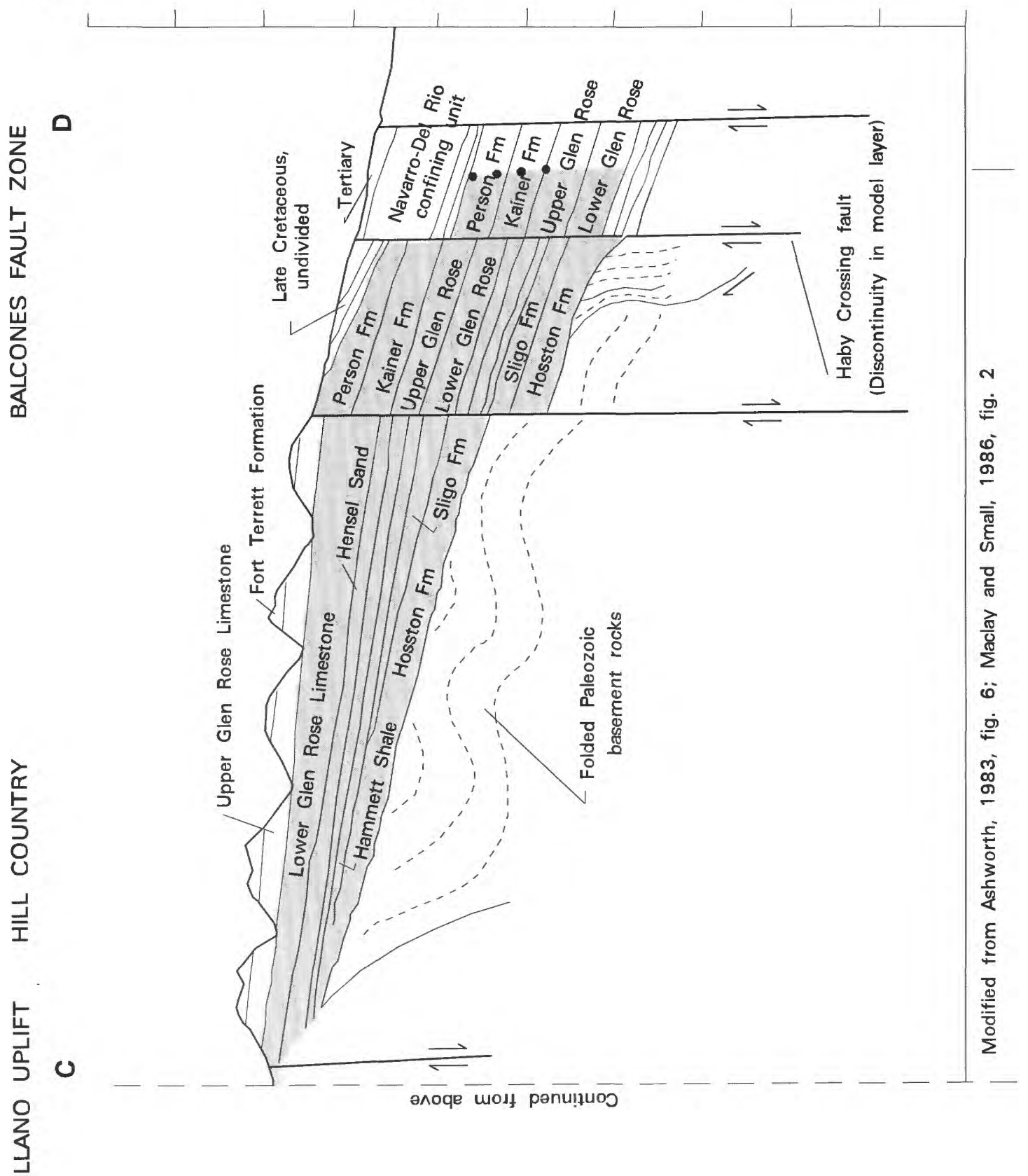


Another simplification for modeling was to assume steady-state conditions. For a large part of the study area, few data are available for transient simulation, and in general, hydrographs for wells located away from principal ground-water withdrawal points do not indicate large seasonal fluctuations (fig. 7). Two hydrographs indicate mining of water, thus, steadystate conditions may not exist near wells 1, 2, and 19 (fig. 7). In the Balcones fault zone, the Edwards aquifer is never in steady state. Long-term water-level records show that annual fluctuations of 50 to $100 \mathrm{ft}$ are common (Nalley, 1989, table 5). During winter 1974-75, water levels were rising in the Balcones fault zone, and thus, water was going into storage within the aquifer during that time.

In a steady-state simulation, recharge must equal discharge, therefore the amount of actual recharge to the Edwards aquifer could be greater than the amount simulated. The average water-level rise in 16 wells throughout the Edwards aquifer was $4.2 \mathrm{ft}$ from December 1974 through February 1975. The average rise in four wells in Bexar County was $3.75 \mathrm{ft}$. Using the previously discussed water-level-storage relation of Garza (1966), which indicates that about 40,000 acre-ft of water is taken into storage for each foot of waterlevel rise, the estimated amount of water that went into storage is 150,000 acre- $\mathrm{ft}$ for the 3 months. This amount is one-half the estimated recharge for that period. Thus, the recharge applied in the simulation should be reduced to one-half the actual recharge.

The ground-water flow equation solved by the flow model is the continuity equation for flow with the incorporation of Darcy's law, derived from the principal of conservation of mass and the assumptions that water is incompressible and of constant viscosity (Raudkivi and Callander, 1976, p. 43; Bouwer, 1978, p. 202; Bear, 1979, p. 93). This equation is valid for ground-water flow problems when the velocity of ground water is slow and laminar. In karstic terranes, it is quite possible for flow through caverns and dissolution channels to be turbulent. Thus, the equation is not valid for the entire flow domain of the Edwards-Trinity aquifer system. A simplification is to assume laminar flow everywhere and an effective transmissivity that is uniform throughout each element of the model such that conservation of mass is preserved along with known hydraulic gradients.

The finite-element method was chosen for solving the ground-water flow equation because the method allows for the direction of anisotropy to be varied areally. This factor was the most important reason for choosing the finite-element method rather than the finite-difference method. While the general direction of the en echelon faults in the Balcones fault zone is southwest to northeast, in local areas the faults are not parallel to the regional direction. Previous models developed in the study area (Klemt and other, 1979; Slade and others, 1985; Maclay and Land, 1988) used the finite-difference method. Maclay and Land (1988) examined the effects of anisotropy by orienting the finite-difference grid in the average direction of the major faults in the San Antonio part of the Edwards aquifer. The other two modeling studies did not examine the effects of faults and joints.

Another advantage of the finite-element method is the flexibility of developing an irregularly spaced mesh of triangular elements. These elements represent parts of the aquifer system with similar hydraulic properties. The design of a mesh is tedious, but irregular external and internal boundaries can be located more accurately relative to their actual locations. In major areas of the aquifer system, stream-aquifer interaction is important. When using the finite-element method streams are simulated along element sides.

\section{Finite-Element Method}

Solution of the steady-state ground-water flow equation has been discussed in numerous texts, such as Remson and others (1971), Bathe and Wilson (1976), Zienkiewicz (1977), Wang and Anderson (1982), Huyakom and Pinder (1983), Reddy (1986), and Bear and Verruijt (1987). The finite-element method of solving the flow equation differs from the finite-difference method in that it involves piecewise approximation of the flow domain. The flow domain is broken into discrete subdomains, called finite elements. The simplest element is a triangular element with linear sides. The computer program developed for the simulations uses three-nodal triangular finite elements. The computer program incorporates three types of boundary conditions; constant head, constant flux, and head-dependent flux (Kuniansky, 1990a).

\section{Finite-Element Mesh and Lateral Boundaries}

The finite-element mesh designed for this study is shown on plate 1. Because the Edwards-Trinity system is unconfined over most of the model area, the mesh was designed on the basis of surface-water 
drainage divides and streams over the Trans-Pecos, Edwards Plateau, and Hill Country. In the Balcones fault zone, the mesh was designed with elements aligned along the transmissivity subregions defined by Maclay and Small (1986, fig. 20) and the Haby Crossing and Pearson faults (fig. 2). The mesh was also designed such that element sides approximated the boundaries of the geographic subareas shown in figure 1.

The lateral boundaries of the model were defined along hydrologic boundaries where possible. The northeastern boundary of the model follows the Colorado River. The southwestem boundary follows the Rio Grande. These two rivers are simulated as head-dependent sinks. The southeastern boundary is simulated as a no-flow boundary, placed parallel with and downdip of the freshwater/saline-water transition zone. The updip limit of the transition zone $(1,000-\mathrm{mg} / \mathrm{L}$ line of dissolved solids) also marks a sharp change in aquifer transmissivity from more than $100,000 \mathrm{ft}^{2} / \mathrm{d}$ on the freshwater side to less than $1,000 \mathrm{ft}^{2} / \mathrm{d}$ on the brackishwater side. The western boundary in the Trans-Pecos follows the edge of the Cretaceous rocks along the eastern edge of the mountain ranges. This boundary is simulated by head-dependent source nodes. Water enters the Edwards-Trinity aquifer system at the westem edge of the Trans-Pecos from rainfall which percolates into the alluvial fans at the base of the mountains and then into the regional aquifer. A no-flow boundary is placed within the Cenozoic Pecos alluvium aquifer where a Paleozoic ridge of low permeability rocks results in little or no saturated thickness of this aquifer. The only lateral boundary of the model that is somewhat arbitrary is the head-dependent source or sink boundary placed within the High Plains aquifer. The boundary types are indicated on plate 1.

\section{Internal Boundaries}

Perennial streams form the majority of the internal boundaries of the model. The most important internal boundary is the Pecos River. This river is incised into the Edwards-Trinity aquifer, forming a regional drain. It is simulated as a head-dependent source or sink. All other perennial streams inside the model area are simulated in a similar manner. The perennial streams were identified on 7.5-minute topographic maps, and stream heads were estimated by interpolating streambed altitudes along reaches between topographic contours crossing the streams. The dashed lines at the upper reaches of the Concho River and Beals Creek (pl. 1) represent reaches of the river that were simulated in the predevelopment simulation but not in the winter 1974-75 simulation. After development, ground-water levels dropped below these streambeds and the reaches became inactive as drains of the ground-water system.

In the Balcones fault zone, the Pearson and Haby Crossing faults create internal boundaries. Each has 100-percent displacement in the Edwards aquifer (fig. 2). The displacement juxtaposes confining units and less permeable aquifer units horizontally adjacent to the Edwards aquifer (fig. 8). In the finite-element model, elements were aligned along these two faults and a complete discontinuity in the model layer is simulated along parts of these faults. These two lines of discontinuity are shown on plate 1 .

\section{Recharge and Discharge}

Recharge to and discharge from the aquifer are simulated as volume per time applied at each node. Recharge is simulated as a source flow and discharge as a sink flow. In general, these flows change the values in the right-hand-side vector of the system of equations solved (Kuniansky, 1990a, p. 8-11). For this study, the data were processed using geographic information system (GIS) technology to obtain the net flow at each node. Springs and pumping wells are known at specific points. Only Comal and San Marcos Springs had discharge estimated from stream-gage records during winter 1974-75, thus most of the springs are simulated as head-dependent point sinks. Simulated springs are shown on plate 1. Many springs occur along streams and contributed to the base flows of the streams. The effect of these springs is simulated as part of the stream reach, as a head-dependent sink.

To avoid locating nodes at all pumping wells, all pumpage was summed for each element and subtracted from the estimated recharge for each element. The net flow associated with each element was then distributed to the nodes using the GIS preprocessing programs.

Recharge for the Trans-Pecos, Edwards Plateau, and contiguous units was initially applied at estimated rates of 0.1 to $1 \mathrm{in} / \mathrm{yr}$ in a pattem derived from the areal distribution of precipitation. Base flow in the Hill Country was used as the maximum estimate of areally distributed recharge for this subarea. Base flow ranged from 1.57 to 5.96 in/yr during December 1974 to March 1977 (Kuniansky, 1989). 
Recharge to the Edwards aquifer was simulated with areally distributed recharge and direct recharge along the southern reaches of the Blanco, Guadalupe, Medina, Sabinal, Frio, and Nueces Rivers, and Barton, Slaughter, Onion, Verde, Hondo, and Seco Creeks, where these streams and creeks cross the outcropped Edwards aquifer. The streams and creeks lose all of their flow to the Edwards aquifer and usually are dry except during storms or floods. For the West Nueces River and Cibolo Creek, all the recharge was distributed areally over the drainage area in outcropped rocks of the Edwards aquifer. The amount of recharge applied to the San Antonio part of the Edwards aquifer was reduced by 50 percent to account for the estimated amount going into storage during winter 1974-75.

The cones of depression (shown for winter 197475 , fig. 4) on the potentiometric surface in the northwestern part of the Trans-Pecos, Edwards Plateau, and the contiguous units, result from mining of water for many seasons of irrigation. Irrigation withdrawals vary seasonally and annually; thus, the long-term average of estimated irrigation withdrawals was used in the winter 1974-75 steady-state simulation. In these areas, the aquifers are unconfined and there is an appreciable amount of irrigation return flow. The long-term average irrigation withdrawals were reduced by 30 percent to account for irrigation return flow, although Mackey (1987) documented more than 50-percent irrigation return flow in part of the High Plains aquifer, north of the area modeled.

Ground-water withdrawals for the San Antonio area initially were applied to the model at the reported rate. Adjustments to the reported estimates of groundwater withdrawals were required as part of the calibration process to get better simulation results.

\section{Calibration}

The purpose of model calibration is to refine the conceptual model of the Edwards-Trinity aquifer system and develop a set of parameters and stresses that result in a reasonable simulation of the aquifer system. Calibration is accomplished by the adjustment of values for model parameters (transmissivity, leakage coefficient, and anisotropy) and stresses (recharge and discharge), so that there is a good fit between simulated and observed water levels. The parameters and stresses are adjusted within the estimated ranges described in the hydrogeologic setting section. The best available potentiometric map of the aquifer system in the modeled area is the map for the winter of 1974-75, because the data represent the same period of time. Thus, the winter of 1974-75 was simulated first, then the predevelopment period.

The parameters considered to be the least known were transmissivity and the amount of anisotropy. In many models, the stresses applied to the system are considered to be known. The uncertainty in rates of irrigation withdrawals and return flow in the Trans-Pecos, northwestern Edwards Plateau, and contiguous units adds a degree of uncertainty to the model calibration that would not exist if withdrawals were better known. However, the calibration resulted in a set of recharge and transmissivity distributions (one of possibly many sets) whose values are within ranges determined from previous studies.

The simulated potentiometric surface for winter 1974-75 is shown on plate 2 along with the difference between the observed water levels and the simulated water levels at 789 observation wells (a positive number indicates the observed water level is higher than the simulated water level). In general this simulated surface resembles the observed potentiometric surface shown in figure 4. An indication of a good fit between simulated and observed data is the root-mean-square (RMS) error (an approximation of the standard deviation where two-thirds of the errors between the observed and simulated water levels are less than the RMS error). For all 789 observations, the RMS error was $96 \mathrm{ft}$.

The worst fit of the simulated surface was in the areas of greatest topographic relief. In the Trans-Pecos, the RMS error was $137 \mathrm{ft}$ for 139 observations, and in the Hill Country, the RMS error was $119 \mathrm{ft}$ for 65 observations. In these areas, the topographic relief is more than $1,600 \mathrm{ft}$. In the Trans-Pecos, some of the water levels that were used to calibrate the model were known only to $\pm 50 \mathrm{ft}$, or the location of the well was known only within a $2-\mathrm{mi}^{2}$ area.

In the Edwards Plateau, the RMS error was $83 \mathrm{ft}$ for 259 observations, and in the Balcones fault zone, the RMS error was $42 \mathrm{ft}$ for 131 observations. Within the contiguous hydraulically connected units, the RMS error was $94 \mathrm{ft}$ for 195 observations. During the winter of 1974-75, there was about a 4-ft rise in water levels within the Balcones fault zone, increasing the RMS error. The RMS errors were considered acceptable.

To obtain the simulated surface initially, recharge was varied along with irrigation withdrawals, as 
discussed previously. Next, transmissivity and leakage coefficients for head-dependent flux terms were modified. After about 50 trial and error simulations, a parameter estimation procedure was applied for changing transmissivity only (Aral and Kuniansky, 1983). After each iterative parameter estimation process, anisotropy was refined and the procedure started again. During the calibration process, a better fit was achieved in the fault zone by making some of the areas with faults isotropic. This was done in areas where there were joints and lineaments perpendicular to the strike of the fault zone (Wermund and others, 1978).

After preliminary calibration to the potentiometric surface for the winter of 1974-75, a predevelopment simulation was run and compared to the estimated predevelopment surface (fig. 5). The recharge rates were adjusted for both simulated time periods, so that longterm average annual recharge was applied for all areas except the Balcones fault zone. Estimated irrigation pumpage was not considered accurate, and this stress was changed from the original long-term average. In the Trans-Pecos and Edwards Plateau, the long-term average irrigation pumpage was reduced by 56 percent for the simulation results presented. This is slightly greater than the estimated irrigation return flow of 50 percent for the High Plains aquifer and much greater than the estimate of 20-percent irrigation return flow for the Cenozoic Pecos alluvium aquifer.

The simulated predevelopment surface is shown in figure 9. No RMS error is computed between the simulated predevelopment surface and the predevelopment surface obtained from historical observations because the observed data were collected over several decades. The simulated predevelopment surface is different from the simulated winter 1974-75 surface in Reeves County and the northwestern part of Pecos County in the Trans-Pecos. In the Edwards Plateau, the surfaces differ in Glasscock, Midland, and the northern part of Upton and Reagan Counties. In these areas, the simulated winter surface is drawn down from the predevelopment surface resulting from ground-water withdrawals. The simulated drawdown is greater than $600 \mathrm{ft}$ in the Trans-Pecos and greater than $200 \mathrm{ft}$ in the Edwards Plateau.

For both simulations, transmissivity, anisotropy, and recharge were the same. Ranges in transmissivity, anisotropy, and recharge for both steady-state simulations are shown in figures 10,11 , and 12 , respectively.

In the Hill Country, the recharge amounts that did not cause mounding of water levels were less than the base flows of the streams. This reduction in estimated recharge results from the numerous springs and seeps along the hillsides that are part of local flow systems that cannot be simulated by a single-layer model of regional scale.

In the Balcones fault zone, the total recharge was reduced by 60 percent to account for the amount of water that went into storage in the aquifer (this is $\mathbf{1 0}$ percent greater than the estimated amount that goes into storage). The municipal and industrial pumpage data compiled by Lurry and Pavlicek (1991) was increased by 20 percent to account for unreported withdrawals and underestimated withdrawals. Both of these changes gave a better fit to observed water levels and springflows.

\section{Sensitivity Analysis}

Sensitivity analysis provides an indication of how the selection of model parameters and stresses affect the model response. For ground-water flow models, the model response is the simulated water level and flow through the system. A model is considered sensitive to a parameter or stress when a small change (perturbation) of the parameter or stress causes a large change in the simulated water level. Sensitivity analysis is useful for indicating areas where errors in the calibrated set of parameters and stresses are more likely. If the model is sensitive to changes in a parameter or stress, then it is more likely that the calibrated value is accurate. If the model is insensitive to changes in a parameter or stress, then it is unknowable if the calibrated value is close to the actual value.

Sensitivity analysis was accomplished by changing one parameter or stress at a time (perturbing the parameter) and plotting a graph of the sensitivity simulation RMS error for winter 1974-75 versus the ratio of the perturbed parameter divided by the final simulation value (calibrated value) of the parameter. The parameters tested were transmissivity, angle of anisotropy, relative magnitude of anisotropy, and leakage coefficient for head-dependent-flux nodes. The stresses tested were recharge and pumpage. Graphs for all six tests for the total model area, each of the four subareas, and the contiguous units are shown in figure 13.

All subareas except the Balcones fault zone were more sensitive to a reduction in transmissivity than to an increase in transmissivity. The Trans-Pecos, contiguous units, and Edwards Plateau were the most 


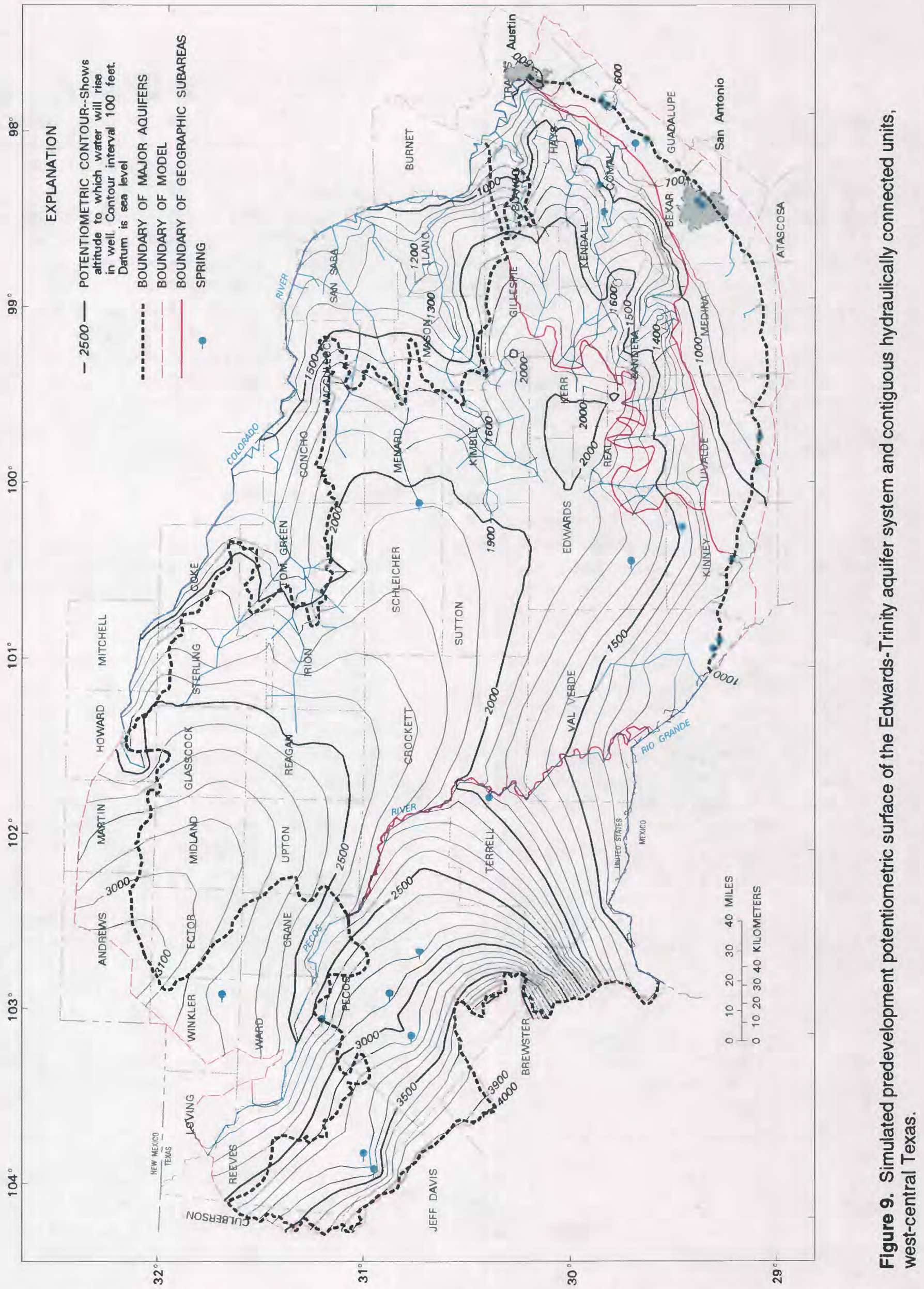




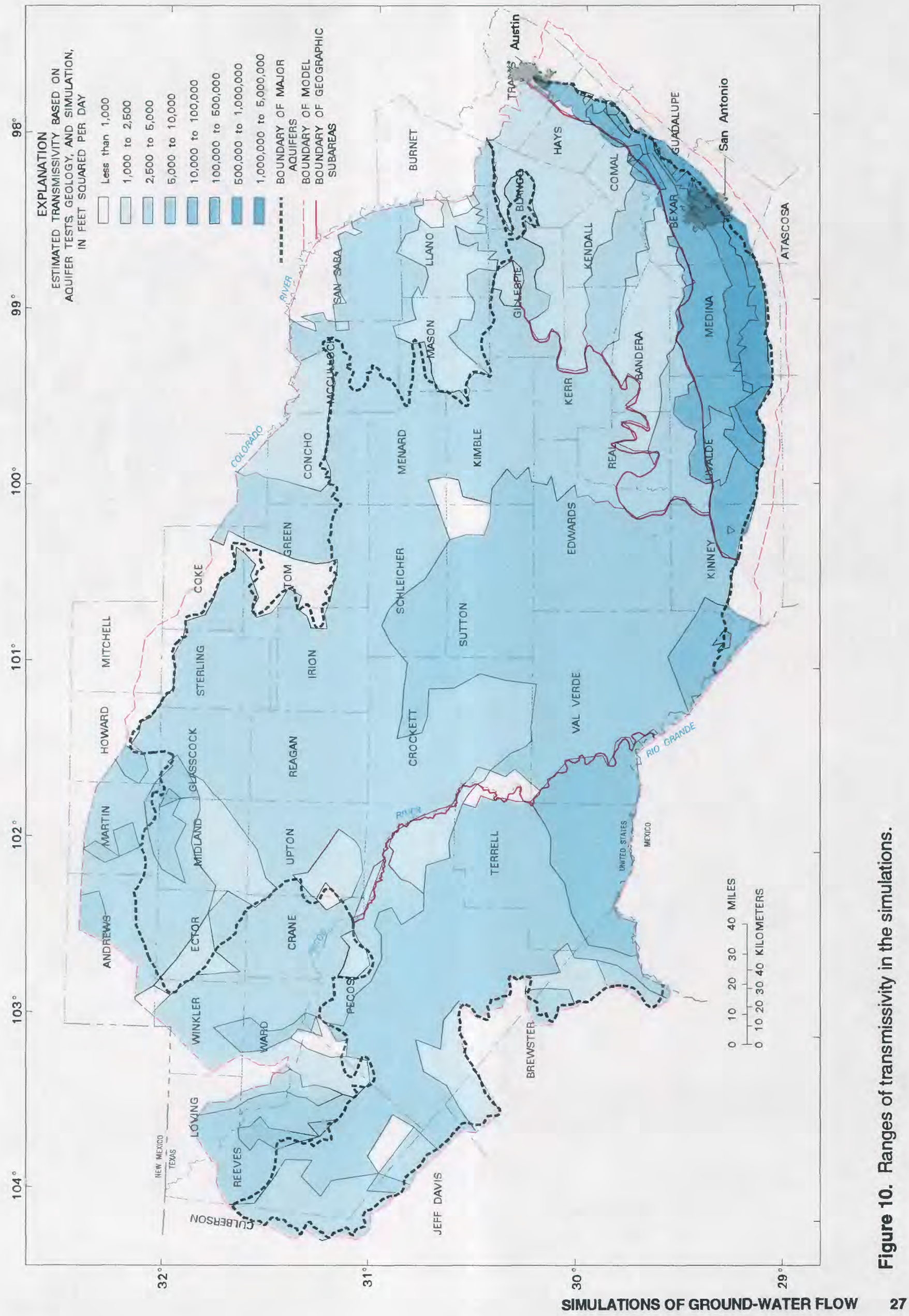




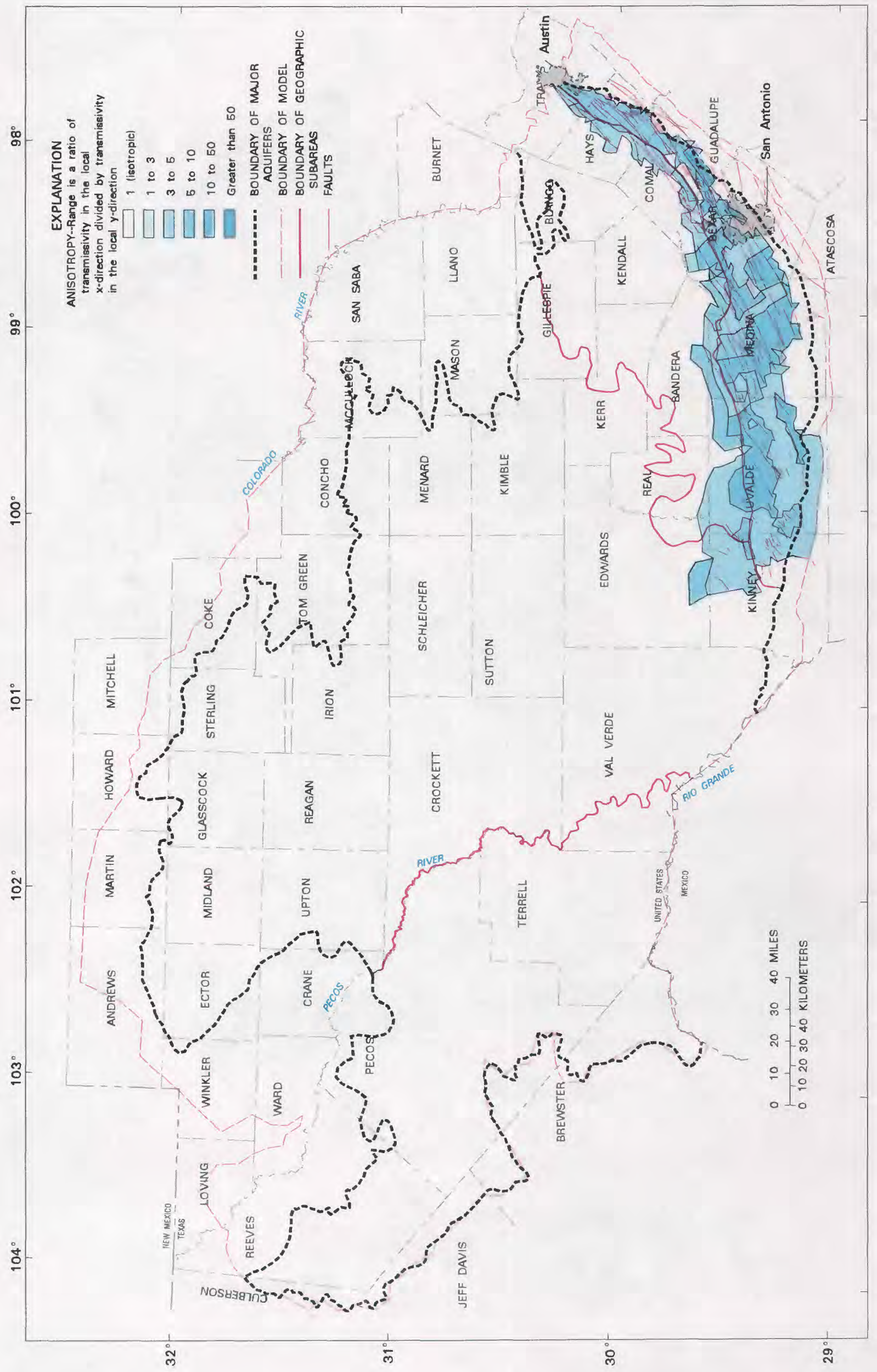

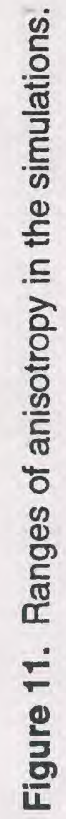




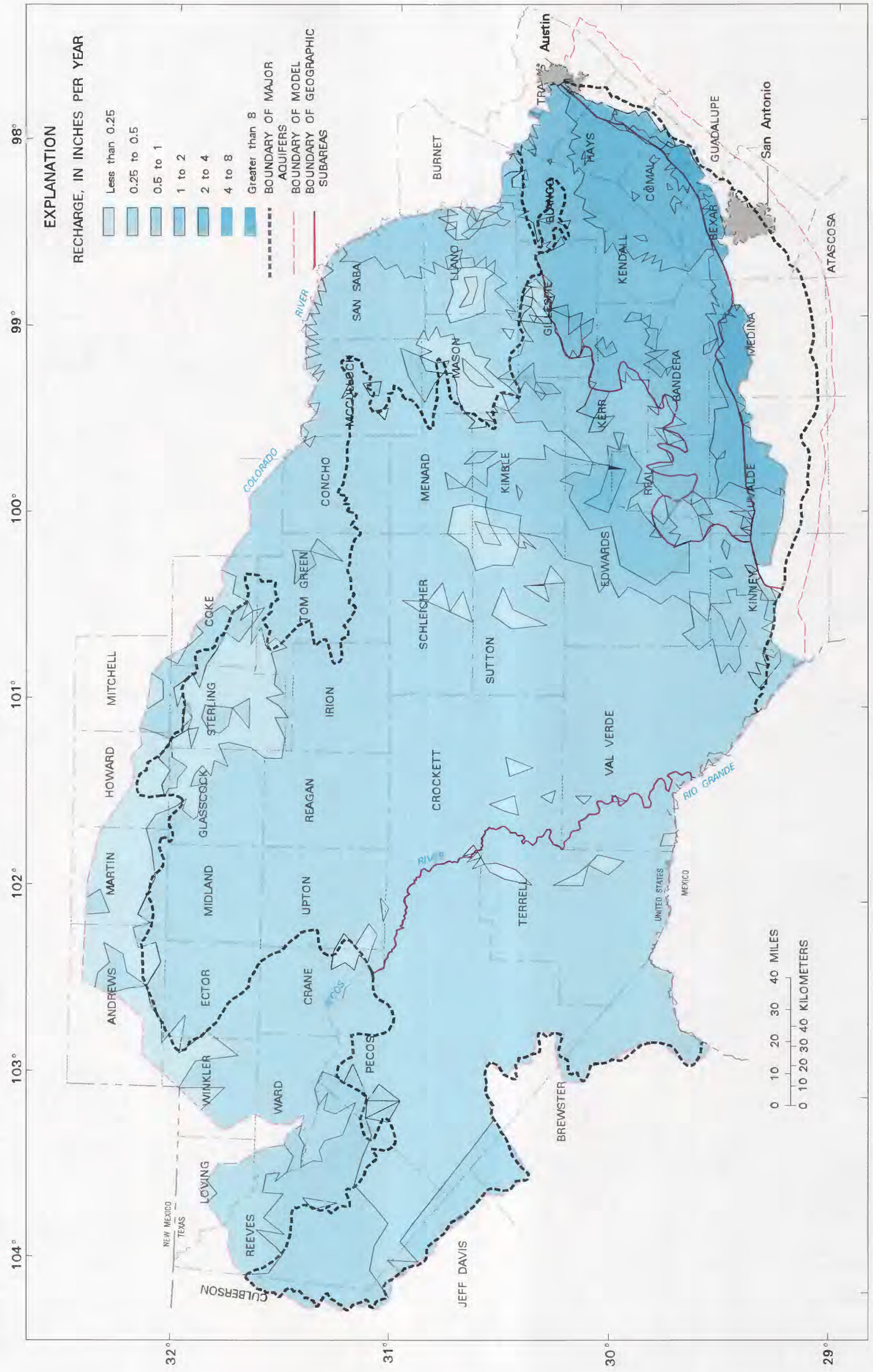

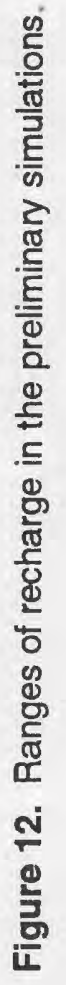



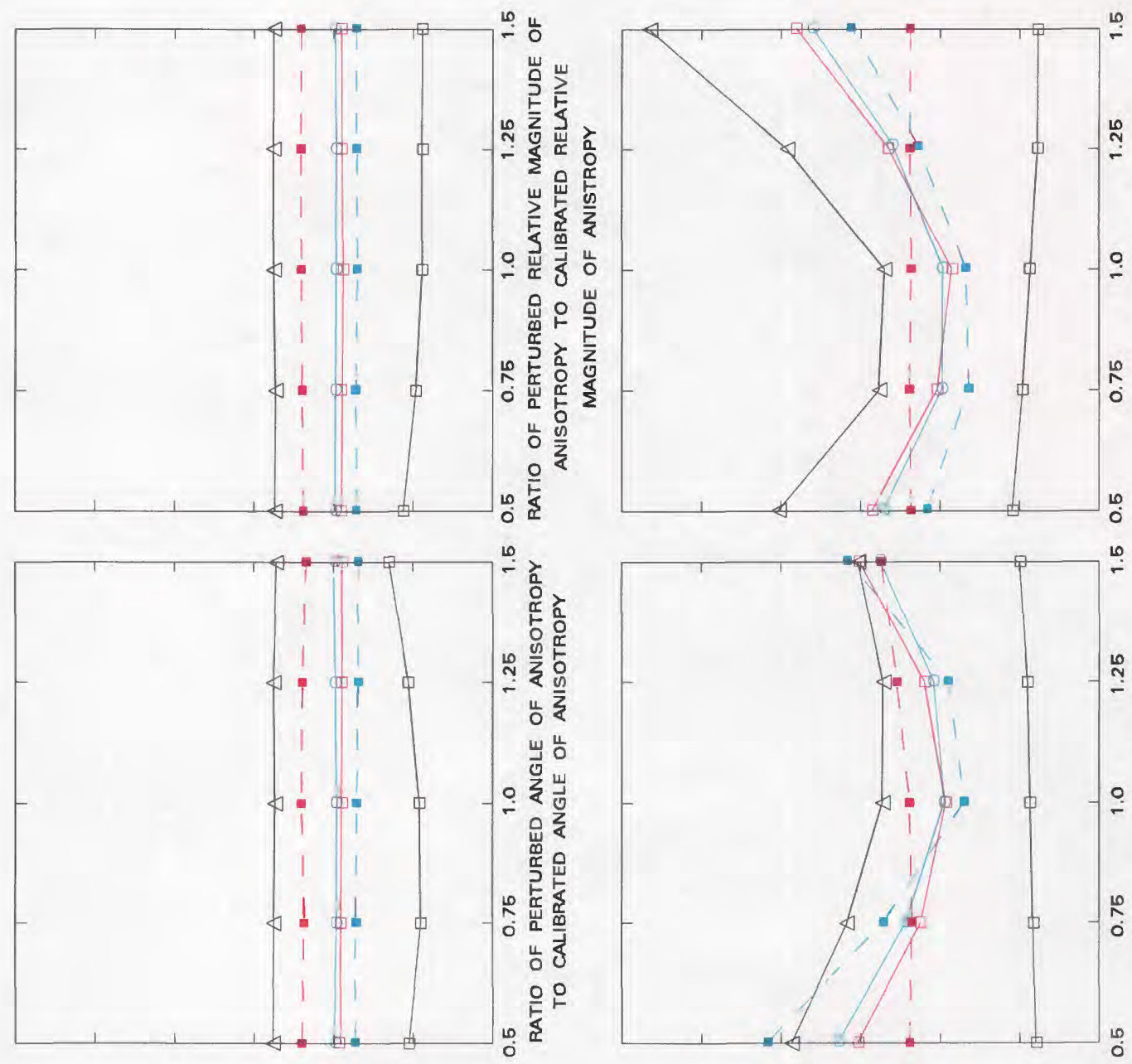

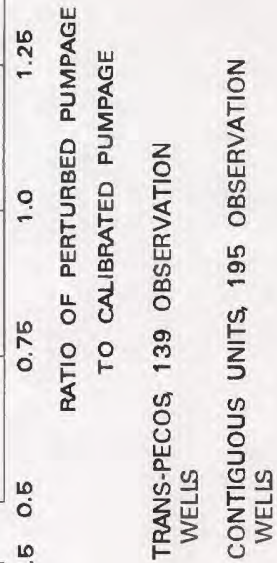
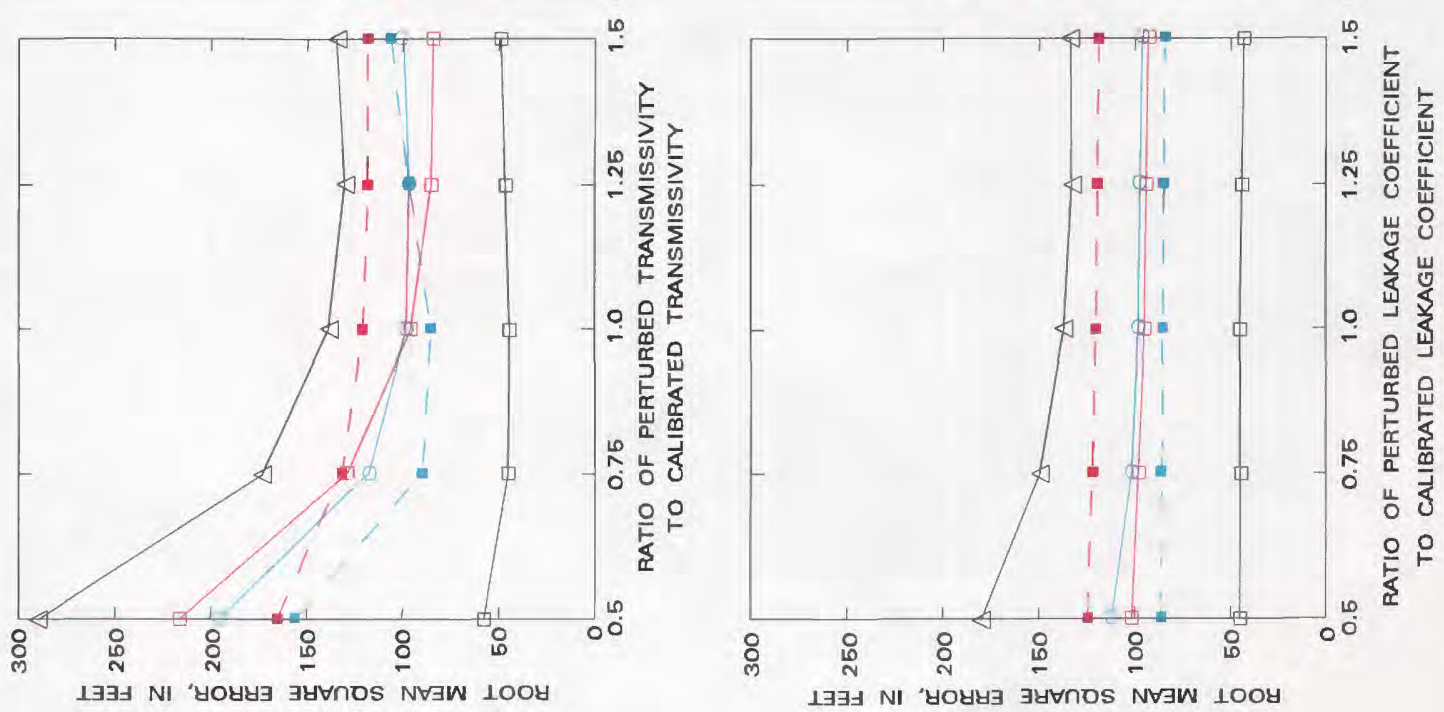

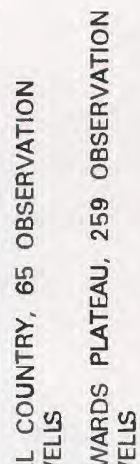

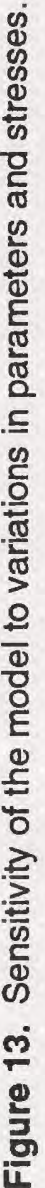


sensitive because of the small transmissivities in these areas. When transmissivity is small, a further reduction makes the aquifer behave more like a confining unit. In comparison, the Balcones fault zone was less sensitive to transmissivity change resulting from transmissivities greater than 2 million $\mathrm{ft}^{2} / \mathrm{d}$ in the Edwards aquifer. When transmissivities exceed $10^{5} \mathrm{ft}^{2} / \mathrm{d}$, doubling the value does not affect the water level. Thus, the model will seem insensitive.

Anisotropic conditions were simulated in the Balcones fault zone and part of the Hill Country where faults and joints have been extensively mapped and studied. For this reason, subareas of the model where anisotropic conditions were not simulated were insensitive to changes in the angle of anisotropy or the amount of anisotropy. Because the angle of anisotropy is measured counterclockwise from the $\mathrm{x}$-axis (that parallels west to east), a decrease in the angle of anisotropy has the effect of allowing water to move more easily in an east-west direction, rather than in the southwest-northeast orientation of the faults. When the angle of anisotropy is increased, the RMS error increases.

In general, the springs decrease in altitude from west to east in the fault zone. Since the springs are simulated predominantly as head-dependent point sinks with leakage coefficients between $10^{5}$ and $10^{10} \mathrm{ft}^{2} / \mathrm{d}$ (see hydraulic characteristics section for definition of leakage coefficient), the simulated head at spring nodes approximates the specified spring pool elevation (see Kuniansky, 1990a, p. 10, for explanation of headdependent sources or sinks). Increasing the angle of anisotropy creates greater resistance to flow from west to east, resulting in higher simulated heads west of each simulated spring (pl. 1) and a reduction in simulated springflows. The model was insensitive to perturbations in the ratio of maximum to minimum anisotropy; however, removal of anisotropy from the aquifer system resulted in an RMS error of $120 \mathrm{ft}$ in the fault zone, a 270-percent increase from the RMS error associated with calibration conditions.

The model was not very sensitive to changes in the leakage coefficient. This coefficient represents resistance of water movement to or from head-dependent sources or sinks. Because of the size of the elements used in this approximation of the aquifer system, the leakage coefficient for most of the simulated river reaches is a number greater than $10^{5} \mathrm{ft}^{2} / \mathrm{d}$. This could result in the lack of sensitivity of the model to the leakage coefficient. The Trans-Pecos was more sensitive to a reduction of this parameter (more resistance to water movement). The other subareas were not sensitive to an increase or decrease in the parameter.

Recharge is simulated mathematically as the opposite of ground-water withdrawals or natural discharge. Thus, differences in sensitivity in the subareas are related to withdrawals and to the effect of less recharge in arid parts of the study area, where transmissivity also is small. Changes in recharge had the greatest effect on the Edwards Plateau, where the area is semiarid and there are large irrigation withdrawals. In the Trans-Pecos and contiguous units, the location of irrigated fields is near the Pecos River where the winter of 1974-75 simulation shows a reversal of the natural ground-water gradient and water from the Pecos River was flowing to the aquifer near the irrigated fields. Thus, the Trans-Pecos and contiguous units are less sensitive to changes in areally applied recharge. The Hill Country and Balcones fault zone subareas are not very sensitive to changes in recharge, which might result from the larger transmissivity values and the proximity of streams simulated as head-dependent sources or sinks.

The subareas that were sensitive to changes in recharge also were sensitive to changes in withdrawals. The Hill Country and Balcones fault zone were relatively insensitive to changes in pumpage compared to the other subareas, but for different reasons. There is relatively little pumpage of ground water in the Hill Country, therefore, the area is not sensitive to changes in pumpage. In the Balcones fault zone, the transmissivities are so large that even with the large withdrawals in the San Antonio area, there is no cone of depression. In the Trans-Pecos, the model was more sensitive to increases than to decreases in pumpage.

In summary, the more arid parts of the study area (Trans-Pecos, Edwards Plateau, and northwestem part of the contiguous units) are sensitive to changes in transmissivity, recharge, and discharge. The Hill Country is sensitive to reduced transmissivity and increased recharge. The Balcones fault zone is insensitive to most of the changes in parameters and stresses. For this reason, there is uncertainty that the calibrated set of parameters and stresses is the true set of parameters and stresses in the Balcones fault zone. Fortunately, a large data base exists for the Balcones fault zone; thus the estimated values for recharge, ground-water withdrawals, and transmissivity could be more accurate. In the western part of the study area, there is little data on which to base estimates of the parameters and stresses, 
but because the model is more sensitive to changes in the estimated values, the calibrated set of parameters might approximate the true values.

\section{Water Budgets}

In a simplified model of the aquifer system, such as the two-dimensional finite-element model of this report, water enters (recharges) or exits (discharges) the aquifer at nodes and moves horizontally. Because steady-state conditions are imposed, recharge equals discharge in each simulation. The simulations indicate that water flows through the Edwards-Trinity aquifer system and contiguous hydraulically connected units at a rate of nearly 3 million acre- $\mathrm{ft} / \mathrm{yr}$ (about $4,000 \mathrm{ft}^{3} / \mathrm{s}$ ).

The major difference in the water budgets from the postdevelopment and predevelopment simulations is in the distribution of discharge (figs. 14 and 15). After ground-water development, some of the recharge that would have discharged naturally to streams and springs is diverted to wells. Areally distributed recharge represented long-term average rates in the Trans-Pecos, Edwards Plateau, Hill Country, and northwestern part of the contiguous units and was the same for both simulations. Springflows and groundwater discharge through the streambeds is greater prior to development. Discharge to streams after development is 20 percent less than the predevelopment discharge to streams, and springflow in the system is 30 percent less than predevelopment springflow. After development, there is some induced recharge from some of the streams, and many of the springs cease to flow as a result of a lowering of the water table (table 2). The recharge from streams is 12 percent greater than predevelopment rates. Withdrawals after development account for 28 percent of simulated discharge; discharge from the major springs accounts for 24 percent of discharge; and 47 percent of the simulated discharge goes to streams and minor springs. Prior to ground-water development, simulated discharge to major springs was 36 percent of the total discharge, and discharge to streams accounted for 63 percent of the discharge. ${ }^{2}$

In the winter 1974-75 simulation, 39 percent of ground-water withdrawals and 90 percent of the simulated discharge to major springs are within the $\mathrm{Bal}$ cones fault zone. Together, simulated withdrawals and

\footnotetext{
${ }^{2}$ About 1 percent of total discharge is to the High Plains.
}

springflows in the Balcones fault zone account for 33 percent of the discharge for the entire area in winter 1974-75. Prior to development, simulated spring discharge in the Balcones fault zone represented 30 percent of the total discharge for the entire area. While the Balcones fault zone represents 5 percent of the modeled area, about one-third of the simulated flow through the system occurs in this area indicating that it is the most active part of the ground-water flow system.

Matching simulated springflows to the observed values in the Edwards aquifer was difficult. Small errors in simulated water levels result in large errors in springflow when transmissivity is greater than 100,000 $\mathrm{ft}^{2} / \mathrm{d}$. Continuous or periodic discharge measurements exist for a few of the major springs; for most, only periodic or miscellaneous measurements, or estimates, are available. Springflows were specified at San Marcos and Comal Springs (the gaged springs) for the postdevelopment simulation. All springflows were simulated as head-dependent sinks in the predevelopment simulation (table 2). The gaged springs had greater springflow during winter 1974-75, as a result of an extremely wet antecedent fall. The total springflow in the Balcones fault zone was greater for the predevelopment simulation. This results from the addition of discharge from San Pedro Springs and increased discharge at San Antonio Springs west of Comal and San Marcos Springs. The simulated predevelopment springflow at Comal and San Marcos Springs is equal to average discharge (table 2).

Areally distributed recharge accounts for 62 percent of the water entering the ground-water flow model after development and 65 percent for the predevelopment simulation. The distribution of areally distributed recharge is shown in figure 12 . Streams supply 28 and 26 percent of the total recharge for the postdevelopment and predevelopment simulations, respectively. The head-dependent source nodes along the western edge of the model in the Trans-Pecos supply 9 and 8 percent of the recharge for postdevelopment and predevelopment, respectively. The flow entering the contiguous units along the head-dependent nodes in the High Plains is about 1 percent of the total recharge for both simulations.

The majority of recharge from streams occurs in the Nueces, Guadalupe, and Colorado River drainage basins along streams that lose their total flow to the Edwards aquifer where highly permeable rocks are outcropped and the streambed crosses faults and joints near the southern boundary of the Hill Country and 


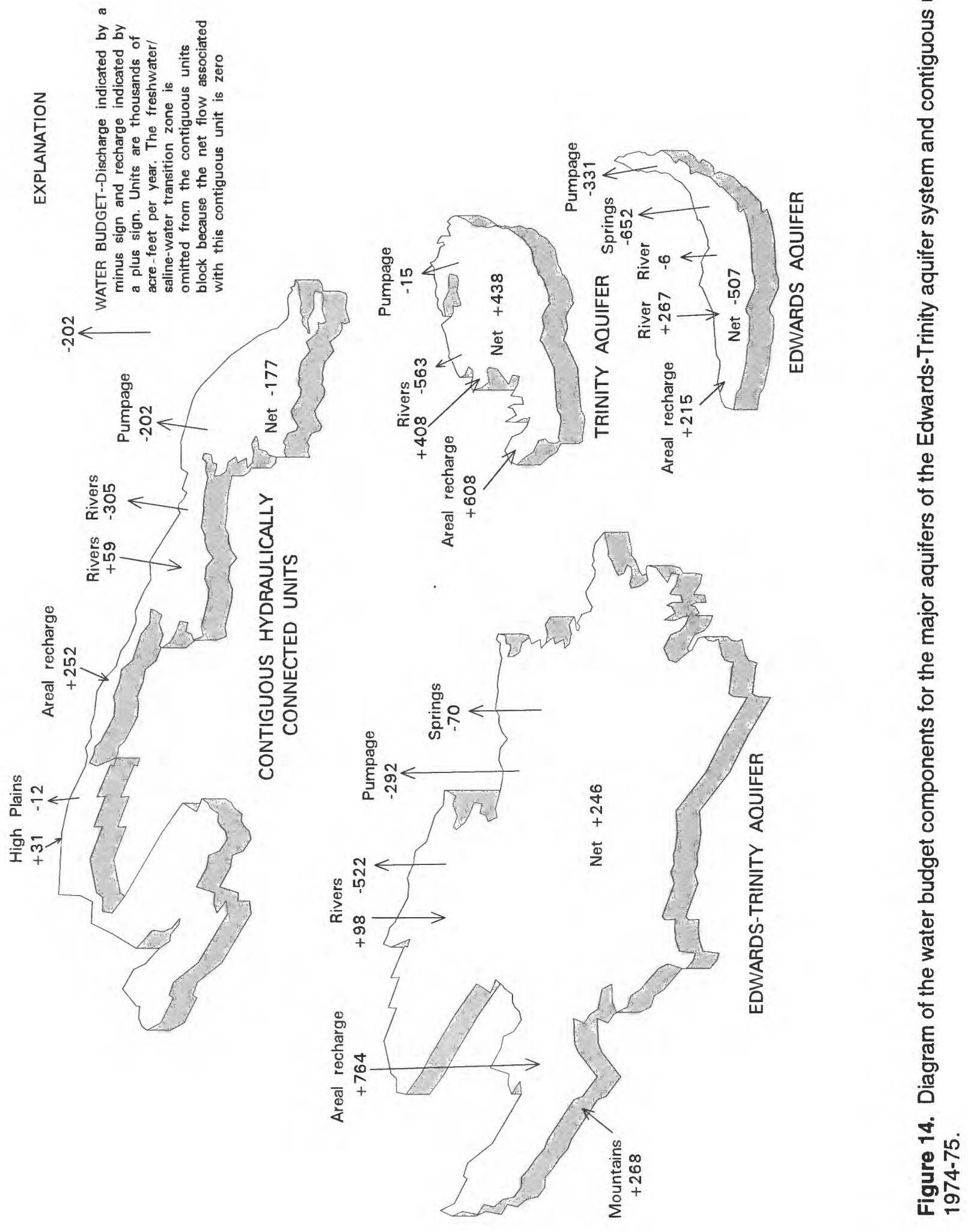

SIMULATIONS OF GROUND-WATER FLOW 


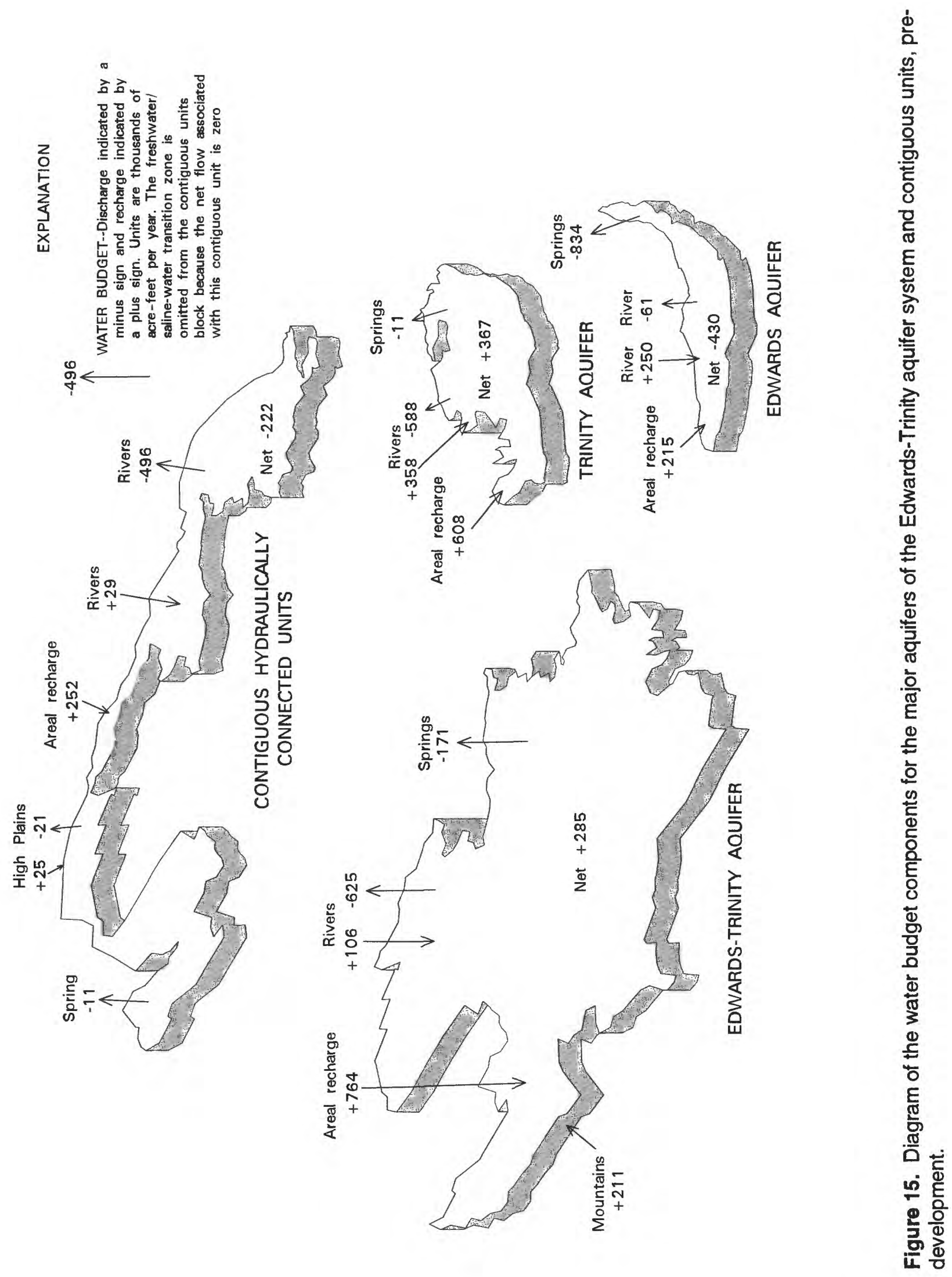


Table 2. Simulated and observed or estimated discharge from major springs

$\left[\mathrm{ft}^{3} / \mathrm{s}\right.$, cubic feet per second]

\begin{tabular}{|c|c|c|c|}
\hline \multirow[b]{2}{*}{ Spring } & \multicolumn{2}{|c|}{ Simulated discharge } & \multirow{2}{*}{$\begin{array}{l}\text { Observed or estimated } \\
\text { discharge }^{1}\end{array}$} \\
\hline & $\begin{array}{l}\text { Predevelopment } \\
\left(\mathrm{ft}^{3} / \mathrm{s}\right)\end{array}$ & $\begin{array}{c}\text { Winter 1974-75 } \\
\left(\mathrm{ft}^{3} / \mathrm{s}\right)\end{array}$ & \\
\hline Comal & 297 & ${ }^{2} 415$ & $\begin{array}{l}\text { Average discharge, }{ }^{3} 294 \mathrm{ft}^{3} / \mathrm{s} ; \\
\text { winter } 1974-75 \text { discharge, } 415 \mathrm{ft}^{3} / \mathrm{s} \text {. }\end{array}$ \\
\hline San Felipe & 60 & ${ }^{2} 80$ & Flow is normally greater than $100 \mathrm{ft}^{3} / \mathrm{s}$. \\
\hline San Marcos & 167 & ${ }^{2} 241$ & $\begin{array}{l}\text { Average discharge, }{ }^{4} 166 \mathrm{ft}^{3} / \mathrm{s} \\
\text { winter } 1974-75 \text { discharge, } 241 \mathrm{ft}^{3} / \mathrm{s} \text {. }\end{array}$ \\
\hline San Antonio & 325 & 88 & $\begin{array}{l}\text { Flow was greater than } 100 \mathrm{ft}^{3} / \mathrm{s} \text { prior to development, } \\
\text { now flow is } 10 \text { to } 100 \mathrm{ft}^{3} / \mathrm{s} \text {. }\end{array}$ \\
\hline Barton & 40 & 34 & $\begin{array}{l}\text { Average discharge, }{ }^{5} 56 \mathrm{ft}^{3} / \mathrm{s} ; \\
\text { winter } 1974-75 \text { discharge, }{ }^{6} 96 \mathrm{ft}^{3} / \mathrm{s} \text {. }\end{array}$ \\
\hline Hueco & 122 & 37 & Flowed 10 to $100 \mathrm{ft}^{3} / \mathrm{s}$ after development. \\
\hline Las Moras & 19 & ${ }^{2} 60$ & Flowed 10 to $100 \mathrm{ft}^{3} / \mathrm{s}$ : \\
\hline Leona & 57 & 25 & Flowed 10 to $100 \mathrm{ft}^{3} / \mathrm{s}$ \\
\hline San Solomon; Giffin & 39 & 16 & Flowed 10 to $100 \mathrm{ft}^{3} / \mathrm{s}$ \\
\hline Comanche & 18 & (7) & Flowed 10 to $100 \mathrm{ft}^{3} / \mathrm{s}$ \\
\hline Fort McKavett & .3 & (7) & Flowed 10 to $100 \mathrm{ft}^{3} / \mathrm{s}$ \\
\hline Leon & 33 & (7) & Flowed 10 to $100 \mathrm{ft}^{3} / \mathrm{s}$ \\
\hline Cantu & 4 & (7) & Flowed 1 to $10 \mathrm{ft}^{3} / \mathrm{s}$ \\
\hline Edge Falls & 6 & (7) & Flowed 1 to $10 \mathrm{ft}^{3} / \mathrm{s}$ \\
\hline Jacob's Well & 6 & (7) & Flowed 1 to $10 \mathrm{ft}^{3} / \mathrm{s}$ \\
\hline Kickapoo & 5 & (7) & Flowed 1 to $10 \mathrm{ft}^{3} / \mathrm{s}$ \\
\hline Rebecca & 4 & (7) & Flowed 1 to $10 \mathrm{ft}^{3} / \mathrm{s}$. \\
\hline Sandia; Saragosa & 26 & (7) & Flowed 1 to $10 \mathrm{ft}^{3} / \mathrm{s}$. \\
\hline San Pedro & 74 & (7) & Flowed 1 to $10 \mathrm{ft}^{3} / \mathrm{s}$ \\
\hline Santa Rosa & 16 & (7) & Flowed 1 to $10 \mathrm{ft}^{3} / \mathrm{s}$ \\
\hline Schwander & 3 & (7) & Flowed 1 to $10 \mathrm{ft}^{3} / \mathrm{s}$ \\
\hline Sink & 9 & (7) & Flowed 1 to $10 \mathrm{ft}^{3} / \mathrm{s}$ \\
\hline Soldiers Camp & 44 & (7) & Flowed 1 to $10 \mathrm{ft}^{3} / \mathrm{s}$. \\
\hline T5 & 2 & (7) & Flowed 1 to $10 \mathrm{ft}^{3} / \mathrm{s}$ \\
\hline Tunas & 30 & (7) & Flowed 1 to $10 \mathrm{ft}^{3} / \mathrm{s}$ \\
\hline Willow & 16 & (7) & Flowed 1 to $10 \mathrm{ft}^{3} / \mathrm{s}$ \\
\hline
\end{tabular}

\footnotetext{
${ }_{1}^{1}$ Ranges in discharge obtained from Brune $(1975,1981)$, except Barton, Comal, and San Marcos Springs which are gaged.

${ }^{2}$ Discharge specified in winter $1974-75$ simulation.

${ }^{3}$ Average discharge, water years 1933-89 (Buckner and others, 1989).

${ }_{5}^{4}$ Average discharge, water years 1957-89 (Buckner and others, 1989).

5 Average discharge, water years 1918, and 1979-89 (Buckner and others, 1989).

${ }^{6}$ Estimated discharge for winter 1974-75 (Slade and others, 1986).

${ }^{7}$ Spring not simulated, winter 1974-75.
} 
northern boundary of the Balcones fault zone. After ground-water development, there is some flow to the Cenozoic Pecos alluvium aquifer along the Pecos River where large ground-water withdrawals for irrigation occur near the river. In topographically rugged places along the eastem and southeastem margin of the Edwards Plateau, streams originate from the discharge of local ground-water flow systems. The local flow systems occur at higher altitudes than the simulated regional flow system. Thus, near the headwaters of some streams, the altitudes of the streambeds are above the simulated surface and these simulated reaches recharge the aquifer (pl. 1).

The water budgets for both simulations indicate that the Edwards-Trinity and Trinity aquifers are predominantly in recharge areas. Part of the contiguous units and the Edwards aquifer are predominantly in discharge areas. Lateral movement of water from the recharge areas to the discharge areas results in a mass balance for each block shown in figures 14 and 15 . The majority of the net recharge to the Edwards-Trinity aquifer flows laterally through parts of the contiguous units toward the Pecos and Colorado Rivers and their tributaries. Water also flows laterally into the Edwards aquifer from the Edwards-Trinity aquifer. The bulk of the net recharge to the Trinity aquifer in the Hill Country flows laterally toward the Edwards aquifer.

The lateral movement of water into the Edwards aquifer from the Trinity and Edwards-Trinity aquifers is about $3\left(\mathrm{ft}^{3} / \mathrm{s}\right) / \mathrm{mi}$ after development and $2\left(\mathrm{ft}^{3} / \mathrm{s}\right) / \mathrm{mi}$ prior to development along the simulated $221-\mathrm{mi}$ boundary (figs. 14 and 15). This is a significant amount of lateral movement into the Edwards aquifer, more than $500 \mathrm{ft}^{3} / \mathrm{s}$. Maclay and Land (1988, p. A42-43) speculate that there may be cross-formational flow between the Edwards aquifer and the Trinity aquifer where these aquifers are juxtaposed against each other. Slade and others $(1985$, p. 13) found evidence of crossformational flow. Maclay and Land (1988) inferred that a "significant" amount of flow may move from the Lower Glen Rose Limestone (Trinity aquifer) near Cibolo Creek, Medina Lake, and along parts of the Haby Crossing fault. In this model, part of the Haby Crossing fault is simulated as a complete discontinuity (fig. 2 and pl. 1). Lateral movement from the Trinity aquifer to the Edwards aquifer is simulated across the part of the Haby Crossing fault where the Trinity aquifer is horizontally juxtaposed to the Edwards aquifer in Bexar County. Previous model studies assumed a noflow boundary between the horizontally adjacent Trin- ity aquifer from the Hill Country into the Balcones fault zone.

\section{Direction of Ground-Water Movement}

The direction of ground-water movement for the simulation of winter 1974-75 is shown on plate 3 . The illustration shows direction and relative magnitude of the flow per unit width (transmissivity times gradient) for each element of the mesh. The vectors were computed by determining the hydraulic gradient for each element and multiplying it by the transmissivity of the element. The relative magnitude is indicated by the length of each vector, not by the density of vectors. The density of vectors results from the size and number of elements in an area.

In general, the simulation results indicate flow toward the perennial streams and major springs. Movement toward areas with major ground-water withdrawals is not as obvious. For example, in the Balcones fault zone, vectors do not indicate movement toward the municipal and industrial wells for the San Antonio area in Bexar County (compare fig. 6 to vectors on pl. 3). Movement is indicated toward the irrigation withdrawals in Reeves, Pecos, and Glasscock Counties. The flows of the greatest magnitude are in the Balcones fault zone where transmissivity is the largest. Water movement is the most sluggish in the freshwater/ saline-water transition zone adjacent to the Edwards aquifer where transmissivity is small (less than 1,000 $\left.\mathrm{ft}^{2} / \mathrm{d}\right)$.

Along the Pecos River in Reeves County, there is some movement of water from the river toward the cone of depression. In the predevelopment simulation, the flow was toward the Pecos River in this area (fig. 9). Simulated ground water flows east from the westem edge of the model toward the Pecos River and south at the southwestern part of the Trans-Pecos from the mountains toward the Rio Grande. For both simulations ground water was moving from the Edwards Plateau toward the Pecos and Colorado Rivers and the Rio Grande.

Within the Edwards aquifer in the Balcones fault zone, the general direction of ground-water movement is from southwest to northeast with the exception of the westward movement of flow toward Las Moras Spring at the western edge of this subarea in Kinney County. Movement of ground water tends to parallel the freshwater/saline-water transition zone at the southem edge 
of the Edwards aquifer. In the unconfined part of the Edwards aquifer (fig. 2), ground water enters the aquifer and flows southwestward before turning to the northeast. The predominant southwest-to-northeast movement is caused by anisotropy and the relative elevation of the springs, which are the natural discharge points of the Edwards aquifer.

The vectors shown on plate 3 can be compared to the potentiometric surface shown on plate 2 . In areas where the aquifer is simulated as an isotropic aquifer, the vectors are perpendicular to the potentiometric contours. In the Balcones fault zone where the aquifer, has been simulated as anisotropic, the vectors are not perpendicular to the potentiometric contours.

\section{CONCLUSIONS}

Digital modeling of a ground-water flow system is a tool for quantification of the water movement in the aquifer system. The simulations of the Edwards-Trinity aquifer system were accomplished using a simplified model representing the entire system as one layer and assuming steady-state conditions. One simulation was of the winter of 1974-75, for which there was adequate water-level information for calibration. The other simulation was of predevelopment conditions. For the Edwards-Trinity aquifer system in the Trans-Pecos and Edwards Plateau, this simplified approach cannot be refined unless means are developed to acquire more accurate data to use in a model. In the Hill Country and Balcones fault zone, the Trinity and Edwards aquifers are more complex, and the assumption of a one-layer system may not be accurate.

The simulations indicate that the total amount of water flowing through the Edwards-Trinity aquifer system and contiguous hydraulically connected units is about 3 million acre-ft/yr ( $1 \mathrm{in} / \mathrm{yr})$ over the modeled area. During winter 1974-75, 71 percent of the total ground-water discharge was to springs and streams, and withdrawal demands were about 28 percent. Comparison of the water budgets for the two simulations indicates that ground-water development reduced springflow by 30 percent and leakage to streams by 21 percent from the predevelopment simulation. Onethird of the discharge from the entire model occurred within the Balcones fault zone, which represents 5 percent of the study area.

Large irrigation withdrawals from the EdwardsTrinity aquifer and the Cenozoic Pecos alluvium aquifer in the Trans-Pecos subarea resulted in several springs drying up, including Comanche and Leon Springs. Simulations indicate a 20-percent reduction of ground-water discharge to the Pecos River, Rio Grande, and tributaries of the Colorado River after ground-water development.

The impoundment of water in reservoirs along the Colorado, Medina, and Guadalupe Rivers has resulted in some simulated recharge along these streams in the winter 1974-75 simulation. There was also some induced recharge along the Pecos River near the large irrigation withdrawals in Reeves and Pecos Counties. Recharge along simulated streams for the winter of 1974-75 simulation increased by 11 percent from the predevelopment simulation.

The major departure from past simulations of the Edwards aquifer in the Balcones fault zone is in allowing hydraulic connection from the Trinity aquifer. The simulated amount of water entering the Edwards aquifer from the Trinity and Edwards-Trinity aquifers was significant [more than $500 \mathrm{ft}^{3} / \mathrm{s}$ or $2.5\left(\mathrm{ft}^{3} / \mathrm{s}\right) / \mathrm{mi}$ along the simulated 221-mi boundary].

Results indicate that anisotropy is an important factor in ground-water movement in the Balcones fault zone, but the ratio of maximum to minimum transmissivity is not always related to known fault displacement. Areas where joints and fractures were perpendicular to the strike of the faults were simulated as isotropic, resulting in a better simulation of the fault zone. Ignoring anisotropy and simulating ground-water flow in the Edwards aquifer as isotropic resulted in poor simulation of flow in the Edwards aquifer.

\section{REFERENCES CITED}

Aral, M.M., and Kuniansky, E.L., 1983, Aquifer parameter prediction by numerical modeling: Environmental Resource Center, Georgia Institute of Technology Technical Report ERC-02-03, 83 p.

Ardis, A.F., and Barker, R.A., 1993, Historical saturated thickness of the Edwards-Trinity aquifer system and selected contiguous hydraulically connected units, west-central Texas: U.S. Geological Survey WaterResources Investigations Report 92-4125, scale 1:750,000, 2 sheets.

Ashworth, J.B., 1983, Ground-water availability of the Lower Cretaceous formations in the Hill Country of south-central Texas: Texas Department of Water Resources Report 273, 173 p.

1990, Evaluation of ground-water resources in parts of Loving, Pecos, Reeves, Ward, and Winkler Counties, 
Texas: Texas Water Development Board Report 317 , $51 \mathrm{p}$.

Ashworth, J.B., and Christian, P.C., 1989, Evaluation of ground-water resources in parts of Midland, Reagan, and Upton Counties, Texas: Texas Water Development Board Report 312, 52 p.

Barker, R.A., and Ardis, A.F., 1992, Configuration of the base of the Edwards-Trinity aquifer system and hydrogeology of the underlying pre-Cretaceous rocks, westcentral Texas: U.S. Geological Survey WaterResources Investigations Report 91-4071, 25 p.

Barker, R.A., Bush, P.W., and Baker, E.T., Jr., 1994, Geologic history and hydrogeologic setting of the EdwardsTrinity aquifer system, west-central Texas: U.S. Geological Survey Water-Resources Investigations Report 94-4039, $50 \mathrm{p}$.

Bathe, K.J., and Wilson, E., 1976, Numerical methods in finite-element analysis: New Jersey, Prentice Hall, $365 \mathrm{p}$.

Bear, Jacob, 1979, Hydraulics of groundwater: New York, McGraw-Hill, 567 p.

Bear, Jacob, and Verruijt, Arnold, 1987, Modeling groundwater flow and pollution; with computer programs for samples cases: Dordrecht, Boston, D. Reidel Publishing Co., $414 \mathrm{p}$.

Bouwer, Herman, 1978, Groundwater hydrology: New York, McGraw-Hill, 480 p.

Brand, J.P., and Deford, R.K., 1958, Comanchean stratigraphy of Kent quadrangle, Trans-Pecos, Texas: Bulletin of the American Association of Petroleum Geologists, v. 42 , no. 2, p. 371-386.

Brune, Gunnar, 1975, Major and historical springs of Texas: Texas Water Development Board Report 189, 94 p. 1981, Springs of Texas: Fort Worth, Branch-Smith, Inc., v. 1, $566 \mathrm{p}$.

Buckner, H.D., Shelby, W.J., and Davidson, H.J., 1990, Water resources data for Texas, water year 1989, v. 3: U.S. Geological Survey Water-Data Report TX-89-3, $425 \mathrm{p}$.

Bush, P.W., Ardis, A.F., and Wynn, K.H., 1993, Historical potentiometric surface of the Edwards-Trinity aquifer system and contiguous hydraulically connected units, west-central Texas: U.S. Geological Survey WaterResources Investigations Report 92-4055, 3 sheets.

Fisher, W.L., 1990, Technical factors in Edwards aquifer use and management: Austin, prepared for special committee on the Edwards aquifer, a joint committee of the Texas Senate and House of Representatives, $57 \mathrm{p}$.

Garza, Sergio, 1962, Recharge, discharge, and changes in ground-water storage in the Edwards and associated limestones, San Antonio area, Texas, a progress report on studies, 1955-59: Texas Board of Water Engineers Bulletin 6201, 42 p.
1966, Ground-water resources of the San Antonio area, Texas: Texas Water Development Board Report $34,31 \mathrm{p}$.

Gutentag, E.D., Heimes, F.J., Krothe, N.C., Luckey, R.R., and Weeks, J.B., 1984, Geohydrology of the High Plains aquifer in parts of Colorado, Kansas, Nebraska, New Mexico, Oklahoma, South Dakota, Texas, and Wyoming: U.S. Geological Survey Professional Paper 1400-B, 63 p.

Huyakorn, P.S., and Pinder, G.F., 1983, Computational methods in subsurface flow: Orlando, Fla., Academic Press, Inc., 473 p.

International Boundary and Water Commission, 1985, Operation of Rio Grande international dams and reservoirs: International Boundary and Water Commission United States and Mexico, United States Section Annual Report, $13 \mathrm{p}$.

Karl, T.R., and Knight, R.W., 1985, Atlas of monthly and seasonal precipitation departure from normal (18951985) for the contiguous United States, winter: National Oceanic and Atmospheric Administration Historical Climatology Series 3-12, 181 figs.

Kier, R.S., Garner, L.E., and Brown, L.F., Jr., 1977, Land resources of Texas: Austin, University of Texas, Bureau of Economic Geology Land Resources Laboratory Series 1977, 42 p.

Klemt, W.B., Knowles, T.R., Elder, G.R., and Sieh, T.W., 1979, Ground-water resources and model application for the Edwards (Balcones fault zone) aquifer in the San Antonio region, Texas: Texas Department of Water Resources Report 239, 88 p.

Kuniansky, E.L., 1989, Precipitation, streamflow, and base flow in west-central Texas, December 1974 through March 1977: U.S. Geological Survey Water-Resources Investigations Report 88-4218, 2 sheets.

1990a, A finite-element model for simulation of twodimensional steady-state ground-water flow in confined aquifers: U.S. Geological Survey Open-File Report 90$187,77 \mathrm{p}$.

$1990 \mathrm{~b}$, Potentiometric surface of the Edwards-Trinity aquifer system and contiguous hydraulically connected units, west-central Texas, winter 1974-75: U.S. Geological Survey Water-Resources Investigations Report 89-4208, 2 sheets.

Lee, J.N., 1986, Shallow ground-water conditions, Tom Green County, Texas: U.S. Geological Survey WaterResources Investigations Report 86-4177, 88 p.

Loucks, R.G., 1977, Porosity development and distribution in shoal-water carbonate complexes--subsurface Pearsall Formation (Lower Cretaceous) south Texas, in Bebout, D.G. and Loucks, R.G.. eds., Cretaceous carbonates of Texas and Mexico, applications to subsurface exploration: Austin, University of Texas, Bureau 
of Economic Geology Report of Investigations 89, p. 97-126.

Lozo, F.E., and Smith, C.I., 1964, Revision of Comanche

Cretaceous stratigraphic nomenclature, southern

Edwards Plateau, southwest Texas: Transaction of the

Gulf Coast Association of Geological Societies. v. 14, p. 285-307.

Lurry, D.L., and Pavlicek, D.J., 1991, Withdrawals from the

Edwards-Trinity aquifer system and contiguous

hydraulically connected units, west-central Texas,

December 1974 through March 1977: U.S. Geological

Survey Water-Resources Investigations Report 914021, 1 sheet.

Mackey, G.W., 1987, Comparison of irrigation pumpage and change in water storage of the High Plains aquifer in Castro and Parmer Counties, Texas, 1975-83: U.S. Geological Survey Water-Resources Investigations Report 87-4032, 48 p.

Maclay, R.W., and Land, L.F., 1988, Simulation of flow in the Edwards aquifer, San Antonio Region, Texas, and refinement of storage and flow concepts: U.S. Geological Survey Water-Supply Paper 2336-A, 48 p.

Maclay, R.W., and Small, T.A., 1986, Carbonate geology and hydrology of the Edwards aquifer in the San Antonio area, Texas: Texas Water Development Board Report 296,90 p.

Mason, C.C., 1961, Ground-water geology of the Hickory Sandstone member of the Riley Formation, McCulloch County, Texas: Texas Board of Water Engineers Bulletin $6017,84 \mathrm{p}$.

Miller, B.C., 1984, Physical stratigraphy and facies analysis, Lower Cretaceous, Maverick Basin and Devils River trend, Uvalde and Real Counties, Texas, in Smith, C.I., ed., Stratigraphy and structure of the Maverick Basin and Devils River trend, Lower Cretaceous, southwest Texas: San Antonio Geological Society, p. 3-33.

Mount, J.R., Rayner, F.A., Shamburger, V.M., Jr., Peckham, R.C., and Osborne, F.L., Jr., 1967, Reconnaissance investigation of the ground-water resources of the Colorado River Basin, Texas: Texas Water Development Board Report 51, 107 p.

Muller, D.A., and Price, R.D., 1979, Ground-water availability in Texas, estimates and projections through 2030: Texas Department of Water Resources Report 238, $77 \mathrm{p}$.

Nalley, G.M., 1989, Compilation of hydrologic data for the Edwards aquifer, San Antonio area, Texas, 1988, with 1934-88 summary: Edwards Underground Water District Bulletin 48, $157 \mathrm{p}$.

Ogilbee, William, and Wesselman, J.B., 1962, Geology and ground-water resources of Reeves County, Texas: Texas Water Commission Bulletin 6214, v. I, 193 p.

Puente, Celso, 1975, Relation of precipitation to annual ground-water recharge in the Edwards aquifer, San
Antonio area, Texas: U.S. Geological Survey OpenFile Report 75-298, 31 p.

1976, Statistical analysis of water-level, springflow, and streamflow data for the Edwards aquifer, southcentral Texas: Edwards Underground Water District Report, 58 p.

1978, Method of estimating natural recharge to the Edwards aquifer in the San Antonio area, Texas: U.S. Geological Survey Water-Resources Investigations Report 78-10, 34 p.

Raudkivi, A.J., and Callander, R.A., 1976, Analysis of groundwater flow: London, Edward Arnold, Ltd., $214 \mathrm{p}$.

Reddy, J.N., 1986, Applied functional analysis and variational methods in engineering: New York, McGraw Hill, $546 \mathrm{p}$.

Rees, R.W., 1987, Records of wells, water levels, pumpage, and chemical analyses from selected wells in parts of the Trans-Pecos region, Texas, 1968-1980: Texas Water Development Board Report 301, 256 p.

Rees, Rhys, and Buckner, A.W., 1980, Occurrence and quality of ground water in the Edwards-Trinity (Plateau) aquifer in the Trans-Pecos region of Texas: Texas Department of Water Resources Report 255, 41 p.

Remson, Irwin, Hornberger, G.M., and Molz, F.J., 1971, Numerical methods in subsurface hydrology: New York, John Wiley \& Sons, 389 p.

Riggio, R.F., Bomar, G.W., and Larkin, T.J., 1987, Texas drought; its recent history (1931-1985): Texas Water Commission Report LP 87-04, 74 p.

Rose, P.R., 1972, Edwards Group, surface and subsurface, central Texas: Austin, University of Texas at Austin, Bureau of Economic Geology Report of Investigations 74, $198 \mathrm{p}$.

Slade, R.M., Jr., Dorsey, M.E., and Stewart, S.L., 1986, Hydrology and water quality of the Edwards aquifer associated with Barton Springs in the Austin area, Texas: U.S. Geological Survey Water-Resources Investigation Report 86-4036, 117 p.

Slade, R.M., Jr., Ruiz, Linda, and Slagle, Diana, 1985, Simulation of the flow system of Barton Springs and associated Edwards aquifer in the Austin area, Texas: U.S. Geological Survey Water-Resources Investigations Report 85-4299, $49 \mathrm{p}$.

Slagle, D.L., Ardis, A.F., and Slade, R.M., Jr., 1986, Recharge zone of the Edwards aquifer hydrologically associated with Barton Springs in the Austin area, Texas: U.S. Geological Survey Water-Resources Investigations Report 86-4062, 1 sheet.

Small, T.A., 1986, Hydrogeologic sections of the Edwards aquifer and its confining units in the San Antonio area, Texas: U.S. Geological Survey Water-Resources Investigations Report 85-4259, 52 p. 
Smith, C.I., and Brown, J.B., 1983, Introduction to road log Cretaceous stratigraphy, in Structure and stratigraphy of the Val Verde Basin and Devils River uplift, Texas: West Texas Geological Society Publication 83-77, p. 1-47.

Stricklin, F.L., Jr., Smith, C.I., and Lozo, F.E., 1971, Stratigraphy of Lower Cretaceous Trinity deposits of central Texas: Austin, University of Texas, Bureau of Economic Geology Report of Investigations 71, 63 p.

Sun, R.J., ed., 1986, Regional Aquifer-Systems Analysis program of the U.S. Geological Survey--summary of projects, 1978-84: U.S. Geological Survey Circular $1002,264 \mathrm{p}$.

Texas Water Development Board, 1986, Surveys of irrigation in Texas, 1958, 1964, 1969, 1974, 1979, and 1984: Texas Water Development Board Report 294, 243 p.

U.S. Geological Survey, 1975, Water resources data for Texas, water year 1975: U.S. Geological Survey WaterData Report TX-75-1, v. 3, 510 p.

Walker, L.E., 1979, Occurrence, availability, and chemical quality of ground water in the Edwards Plateau region of Texas: Texas Department of Water Resources Report $235,337 \mathrm{p}$.
Wang, H.F., and Anderson, M.P., 1982, Introduction to groundwater modeling; finite-difference and finiteelement methods: San Francisco, W.H. Freeman and Co., $237 \mathrm{p}$.

Wermund, E.G., Cepeda, J.C., and Luttrell, P.E., 1978, Regional distribution of fractures in the southern Edwards Plateau and their relationship to tectonics and caves: Austin, University of Texas, Bureau of Economic Geology, Geologic Circular 78-2, 14 p.

White, D.E., 1968, Ground-water resources of Upton County, Texas: Texas Water Development Board Report 78, 132 p.

1971, Water Resources of Ward County, Texas: Texas Water Development Board Report 125, 219 p.

Woodruff, C.M., De la Garza, Laura, and Snyder, F.R., 1989, Lineaments and the Edwards aquifer--Barton Springs segment, Travis and Hays Counties, Texas: Edwards Aquifer Research and Data Center, Southwest Texas State University, RI-89, ISBN 0-929469-23-2, 45 p.

Zienkiewicz, O.C., 1977, The finite-element method (3d ed.): London, McGraw-Hill, 787 p. 